\title{
Non-immunological complications following kidney
}

\section{transplantation [version 1; peer review: 3 approved]}

\author{
Abraham Cohen-Bucay (D1,2, Craig E. Gordon³, Jean M. Francis ${ }^{4}$ \\ ${ }^{1}$ Department of Nephrology and Mineral Metabolism, Instituto Nacional de Ciencias Médicas y Nutrición Salvador Zubirán, Mexico \\ City, 14080, Mexico \\ ${ }^{2}$ Nephrology Department, American British Cowdray Medical Center, Mexico City, 05300, Mexico \\ ${ }^{3}$ Division of Nephrology, Tufts Medical Center, Boston, MA, 02111, USA \\ ${ }^{4}$ Renal Section, Boston University Medical Center, Boston, MA, 02118, USA
}

V1 First published: 18 Feb 2019, 8(F1000 Faculty Rev):194
https://doi.org/10.12688/f1000research.16627.1

Latest published: 18 Feb 2019, 8(F1000 Faculty Rev):194

https://doi.org/10.12688/f1000research.16627.1

\section{Abstract}

Kidney transplantation (KT) is the most effective way to decrease the high morbidity and mortality of patients with end-stage renal disease. However, KT does not completely reverse the damage done by years of decreased kidney function and dialysis. Furthermore, new offending agents (in particular, immunosuppression) added in the post-transplant period increase the risk of complications.

Cardiovascular (CV) disease, the leading cause of death in KT recipients, warrants pre-transplant screening based on risk factors. Nevertheless, the screening methods currently used have many shortcomings and a perfect screening modality does not exist. Risk factor modification in the pre- and post-transplant periods is of paramount importance to decrease the rate of $\mathrm{CV}$ complications posttransplant, either by lifestyle modification (for example, diet, exercise, and smoking cessation) or by pharmacological means (for example, statins, anti-hyperglycemics, and so on). Post-transplantation diabetes mellitus (PTDM) is a major contributor to mortality in this patient population. Although tacrolimus is a major contributor to PTDM development, changes in immunosuppression are limited by the higher risk of rejection with other agents. Immunosuppression has also been implicated in higher risk of malignancy; therefore, proper cancer screening is needed. Cancer immunotherapy is drastically changing the way certain types of cancer are treated in the general population; however, its use post-transplant is limited by the risk of allograft rejection. As expected, higher risk of infections is also encountered in transplant recipients. When caring for $\mathrm{KT}$ recipients, special attention is needed in screening methods, preventive measures, and treatment of infection with BK virus and cytomegalovirus. Hepatitis $\mathrm{C}$ virus infection is common in transplant candidates and in the deceased donor pool; however, newly developed direct-acting antivirals have been proven safe and effective in the pre- and post-transplant periods. The most important and

\section{Open Peer Review}

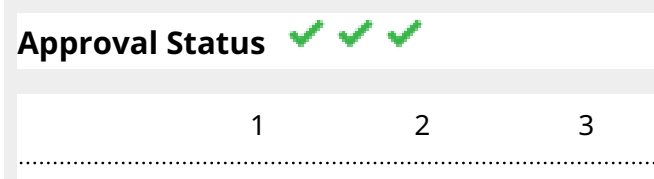

version 1

18 Feb 2019

Faculty Reviews are review articles written by the prestigious Members of Faculty Opinions. The articles are commissioned and peer reviewed before publication to ensure that the final, published version is comprehensive and accessible. The reviewers who approved the final version are listed with their names and affiliations.

1. Jeremy R Chapman, Westmead Hospital, Westmead, Australia

2. Magdalena Durlik, Medical University of Warsaw, Warsaw, Poland

3. Arnaldo Figueiredo, Coimbra University Hospital, Coimbra, Portugal

Any comments on the article can be found at the end of the article. 
recent developments on complications following $\mathrm{KT}$ are reviewed in this article.

Keywords

kidney transplant, post-transplant complications

Corresponding author: Jean M. Francis (Jean.Francis@bmc.org)

Author roles: Cohen-Bucay A: Conceptualization, Writing - Original Draft Preparation; Gordon CE: Conceptualization, Writing - Review \& Editing; Francis JM: Conceptualization, Writing - Review \& Editing

Competing interests: AC-B declares that he has no competing interests. CEG served on a medical advisory board of Abbvie pharmaceuticals, as a consultant to Alexion Pharmaceuticals and on the evidence review team for the 2018 KDIGO guidelines on HCV. JMF served as a consultant to Alexion Pharmaceuticals.

Grant information: The author(s) declared that no grants were involved in supporting this work.

Copyright: (c) 2019 Cohen-Bucay A et al. This is an open access article distributed under the terms of the Creative Commons Attribution License, which permits unrestricted use, distribution, and reproduction in any medium, provided the original work is properly cited.

How to cite this article: Cohen-Bucay A, Gordon CE and Francis JM. Non-immunological complications following kidney transplantation [version 1; peer review: 3 approved] F1000Research 2019, 8(F1000 Faculty Rev):194

https://doi.org/10.12688/f1000research.16627.1

First published: 18 Feb 2019, 8(F1000 Faculty Rev):194 https://doi.org/10.12688/f1000research.16627.1 


\section{Introduction}

End-stage renal disease (ESRD) is one of the leading causes of premature mortality, and the death rate for patients on dialysis is 166 per 1,000 patient-years ${ }^{1}$. Kidney transplant is the best treatment of ESRD and decreases the mortality rate to 29 per 1,000 patient-years ${ }^{1}$. Despite this, kidney transplant recipients still experience a high incidence of complications in the posttransplant period. On one hand, the pre-transplant period, in which the patients had a very low glomerular filtration rate (GFR) and were on renal replacement therapy, inherently confers a high risk of complications which are not completely reversed by a kidney transplant. On the other hand, new factors are added in the post-transplant period, most notably immunosuppressive medications and their side effects. Therefore, the post-transplant period is associated with a wide range of complications, including cardiovascular (CV), metabolic, oncologic, infectious, immunological, surgical, osseous, and hematologic complications. This review will focus on $\mathrm{CV}$, metabolic, oncologic, and infectious complications with an emphasis on areas with important developments in recent years. We chose to review these particular complications because of their frequency and associated mortality in kidney transplant recipients (Table 1). Much of the management and screening of post-kidney transplant complications occurs while the patients are being evaluated for kidney transplant candidacy in the pre-transplant period, which will be reviewed here alongside specific post-transplant management.

\section{Cardiovascular disease}

Chronic kidney disease (CKD) is an independent risk factor for atherosclerotic coronary artery disease (CAD), and CAD incidence and severity increase as the GFR declines ${ }^{2,3}$. By the time patients reach ESRD, the prevalence of coronary artery stenosis ranges from $37 \%$ to $58 \%$ in asymptomatic patients ${ }^{4}$.

Although kidney transplant is the most effective way to decrease the risk of $\mathrm{CV}$ events, $\mathrm{CV}$ death still accounts for $30 \%$ of overall mortality, the most common cause of death in the post-transplant period ${ }^{5}$. The cumulative incidence of myocardial infarction in the post-transplant period is $4.2 \%$ to $11.1 \%$ at
3 years $^{6,7}$. Therefore, two strategies are commonly used to decrease the incidence of $\mathrm{CV}$ disease in post-transplant patients: (1) pre-transplant screening with subsequent treatment and exclusion of very high-risk patients from listing and (2) risk factor modifications in the pre- and post-transplant period.

The most important CV risk factors in the ESRD population include diabetes mellitus (DM), prior CV disease (including stroke and peripheral arterial disease), dialysis vintage of more than 1 year, left ventricular hypertrophy, age greater than 60 years, smoking, hypertension, and dyslipidemia 5 . Many of these risk factors persist in the post-transplant period but others can develop de novo, including post-transplantation diabetes mellitus (PTDM) (previously known as new-onset diabetes after transplantation), drug-induced hypertension, drug-induced dyslipidemia, proteinuria, and chronic inflammation ${ }^{8,9}$. Nontraditional $\mathrm{CV}$ risk factors in the post-transplant period include intrarenal resistive index (RI) greater than 0.80 , which is associated with higher risk of death ${ }^{10}$. Interestingly, the RI during protocol biopsies correlates more with recipients' factors (for example, age and central hemodynamic factors) than with graft or histologic factors ${ }^{10}$. Hypotension in the pre-transplant period might also be a risk factor for adverse outcomes in the posttransplant period, evidenced by recent studies associating the use of midodrine in the pre-transplant period with graft failure, death, and major adverse cardiovascular events (MACE) post-transplant ${ }^{11,12}$.

Identification and optimization of modifiable risk factors are of utmost importance for prevention of $\mathrm{CV}$ events post-transplant. Lifestyle modifications, including exercise, smoking cessation, and maintenance of a healthy weight, are always recommended. Treatment of all post-transplant patients with a statin is suggested by the Kidney Disease Improving Global Outcomes (KDIGO) guidelines on lipid management (grade $2 \mathrm{~A})^{13}$ based on the ALERT (Assessment of Lescol in Renal Transplantation) trial, which showed that fluvastatin decreases the risk of MACE in kidney transplant patients ${ }^{14,15}$. Treatment with reninangiotensin-aldosterone system blockade to decrease proteinuria and hence to decrease $\mathrm{CV}$ risk has not proven to be as effective

Table 1. Incidence and mortality associated with cardiovascular, metabolic, oncologic, and infectious complications in kidney transplant recipients.

\begin{tabular}{|c|c|}
\hline Cardiovascular & $\begin{array}{l}\text { - } 30 \% \text { of overall mortality in kidney transplant patients }{ }^{16,17} \\
\text { - Cumulative incidence of } \mathrm{Ml} \text { at } 3 \text { years: } 4.2 \%-11.1 \%{ }^{6,7} \\
\text { - Mortality: CAD } 4.1(3.0-5.6) / 100 \mathrm{PY}, \text { no CAD } 1.9(1.6-2.1) / 100 \mathrm{PY}^{17}\end{array}$ \\
\hline Diabetes mellitus & $\begin{array}{l}\text { - Incidence of PTDM: about } 12 \% \text { in } 5 \text { years }{ }^{16} \\
\text { - Mortality: DM1 2.3 (1.3-3.7)/100PY, DM2 } 3.7(2.7-5.0) / 100 P Y, \text { no DM 1.8 (1.6-2.1)/100PY } \\
\text { - Increases mortality due to CV (RR 1.5) and infectious (RR 1.87) } \text { causes }^{18}\end{array}$ \\
\hline Cancer & $\begin{array}{l}\text { - } 24 \% \text { of overall mortality in kidney transplant patients }{ }^{17} \\
\text { - Transplantation increases twofold the risk of cancer }\end{array}$ \\
\hline Infections & - $13 \%$ of overall mortality in kidney transplant patients ${ }^{17}$ \\
\hline
\end{tabular}

/100PY, per 100 patient-years; CAD, coronary artery disease; CV, cardiovascular; DM1, diabetes mellitus type 1; DM2, diabetes mellitus type 2; MI, myocardial infarction; PTDM, post-transplantation diabetes mellitus; RR, relative risk. 
as in the general population ${ }^{20-22}$, but larger prospective studies are needed before reaching a definitive conclusion.

The ideal screening strategy is unknown and differs across transplant centers. Current clinical guidelines are based mostly on expert opinion with a low level of evidence, but the general recommendation is the use of a risk-stratified approach in which non-invasive techniques are used first, and coronary angiography is reserved for high-risk patients or when the non-invasive tests are abnormal ${ }^{5,23-26}$. However, clinicians need to be aware that the pre-transplant $\mathrm{CV}$ evaluation should not be the same as for any other non-cardiac surgery, particularly because of the high risk of severe allograft dysfunction (in 6\% to $33 \%$ of patients) and allograft loss (in $3 \%$ to $12 \%$ of patients) if cardiac surgery is required in the post-transplant period ${ }^{27-30}$. Therefore, it is very important to note that the goal of the screening strategy is to decrease the $\mathrm{CV}$ events and mortality not only in the perioperative period but also in the long term ${ }^{5}$.

The risk-stratified approach has proven beneficial for low-risk patients in whom the event rate is very low and invasive tests are therefore unnecessary ${ }^{4}$. This strategy is more controversial for intermediate- and high-risk patients for several reasons. First, the accuracy of stress tests compared with that of coronary angiography is limited (Table 2). In a 2011 meta-analysis, the pooled sensitivity and specificity for dobutamine stress echocardiography (DSE) were 0.79 (95\% confidence interval (CI) $0.67-0.88$ ) and 0.89 (95\% CI 0.81-0.94), respectively. For myocardial perfusion studies (MPS), the pooled sensitivity was $0.74(95 \%$ CI $0.54-0.87)$ and pooled specificity was 0.70 (95\% CI $0.51-0.84)^{31}$. Second, the prognostic value of non-invasive tests has been the subject of controversy. In a 2015 meta-analysis, Wang et $a l .^{32}$ reported that patients with an abnormal DSE have a higher risk of all-cause mortality and MACE but that patients with an abnormal MPS have a higher risk of MACE. However, both tests predicted outcomes poorly: a substantial number of patients with an abnormal non-invasive test did not develop adverse outcomes, while a large proportion of patients who had a normal non-invasive test had adverse cardiac outcomes.

The same meta-analysis ${ }^{32}$ showed that an abnormal coronary angiography was associated with increased risk for all-cause mortality (odds ratio [OR] 2.96, 95\% CI 1.25-7.00) and MACE (OR 16.02, 95\% CI 2.42-105.98). However, coronary angiography was not superior to non-invasive testing at predicting future adverse CV events. Nevertheless, the predictive ability of coronary angiography might have been falsely reduced by revascularization, which significantly decreases MACE (OR 0.19, 95\% CI 0.05-0.72) and all-cause mortality (OR $0.28,95 \%$ CI $0.12-0.64)^{32}$. These results might have also been affected by referral bias given that many of the patients who underwent coronary angiography had an abnormal non-invasive test previously. When revascularization is indicated, this should occur prior to transplantation ${ }^{5}$. However, clinicians need to take into account the need for antiplatelet or anticoagulation treatment after revascularization, which could delay or postpone transplantation.

Therefore, a perfect screening test for CV disease in kidney transplant candidates does not exist and all of the existing strategies have deficiencies. Newer CV tests, including the coronary artery calcium score (CACS) and coronary computed tomography (CT), are now being studied in the ESRD population. The correlation between CACS and angiographic CAD in the CKD/ESRD population is uncertain ${ }^{33-36}$ given that high calcium scores may reflect medial instead of intimal vascular calcifications (Table 2). Nevertheless, CACS has been studied prospectively in two trials in kidney transplant candidates with conflicting results regarding the ability of CACS to predict MACE and mortality in comparison with MPS ${ }^{37,38}$. Therefore, at this time, the CACS cannot be recommended as a first-line strategy for CV disease screening pre-kidney transplant.

Coronary CT has good correlation with angiographic coronary disease $^{34,39}$, and an abnormal coronary $\mathrm{CT}$ is an independent risk factor for adverse $\mathrm{CV}$ outcomes in kidney transplant candidates $^{38,40}$. These results are from relatively small studies and require validation in larger trials with a more diverse population before the widespread use of coronary CT can be recommended as a CV disease screening method in renal transplant candidates. Furthermore, there is a safety concern of performing coronary $\mathrm{CT}$ in patients with residual kidney function given the exposure to iodinated contrast media. Notably, coronary CT is solely a diagnostic modality and in the event of a positive test an invasive coronary angiography and angioplasty

\begin{tabular}{|c|c|c|c|}
\hline Test & Sensitivity & Specificity & Notes \\
\hline $\mathrm{DSE}^{31}$ & $0.79(0.67-0.88)$ & $0.89(0.81-0.94)$ & Meta-analysis of 13 studies $(n=745)$ \\
\hline MPS $^{31}$ & $0.74(0.54-0.87)$ & $0.70(0.51-0.84)$ & Meta-analysis of nine studies $(n=582)$ \\
\hline CACS $^{33-36}$ & $0.54-0.92$ & $0.44-0.87$ & $\begin{array}{l}\text { Four studies, } n \text { ranging from } 18 \text { to } 148 \text {. Total } n=309 . \\
\text { Different cutoff values were used in each study. }\end{array}$ \\
\hline Coronary $\mathrm{CT}^{34,39}$ & $0.65-0.80$ & $0.74-0.86$ & $\begin{array}{l}\text { Two studies, } n \text { ranging from } 19 \text { to } 147 \text {. Total } n=147 \text {. } \\
\text { The larger study reported sensitivity/specificity of } \\
\text { combining three CV risk factors plus coronary CT. }\end{array}$ \\
\hline
\end{tabular}

CACS, coronary artery calcium score; CT, computed tomography; CV, cardiovascular; DSE, dobutamine stress echocardiogram; MPS, myocardial perfusion scan. 
would be needed, requiring a second exposure to iodinated contrast media. Another concern regarding most tests used for $\mathrm{CV}$ disease screening is the required radiation exposure in patients who will subsequently be at higher risk of cancer as a result of post-transplant immunosuppression.

\section{Post-transplantation diabetes mellitus}

Previously, transplant immunosuppressive regimens depended on high doses of corticosteroids, which led to an increased risk of DM after transplant (up to $50 \%$ of transplant recipients ${ }^{41}$ ). Immunosuppression has evolved to rely more on calcineurin inhibitors (CNIs) than on corticosteroids. Despite this, the incidence of PTDM did not decline as expected, leading to the discovery of the diabetogenicity of CNIs, particularly tacrolimus ${ }^{42}$. However, since the early 2000s, the incidence of PTDM has declined ${ }^{16}$, probably due to decreased rates of rejection episodes and reduced exposure to corticosteroids and $\mathrm{CNIs}^{42}$. The 5-year incidence of PTDM according to the 2016 Scientific Registry of Transplant Recipients (SRTR) report is about $12 \%{ }^{16}$.

Both pre-transplant DM and PTDM are associated with higher risk of CV events, graft failure, and mortality ${ }^{6,18,43-45}$. Therefore, early diagnosis and treatment are necessary. However, posttransplant hyperglycemia is dynamic, demonstrated by the transient hyperglycemia seen early post-transplant and during rejection events, both situations requiring high doses of corticosteroids ${ }^{42,46}$. As a result, the consensus is to establish a diagnosis when the patient is stable on their maintenance immunosuppression regimen, with stable kidney function and no acute infections ${ }^{46}$.

Risk factors for PTDM development include type of immunosuppression, ethnicity, obesity, hypomagnesemia, hepatitis $\mathrm{C}$ virus (HCV), and cytomegalovirus (CMV) infection ${ }^{18,42,47-49}$. Lifestyle modification, as well as adjusting the modifiable risk factors such as immunosuppression type and infections, should be taken into account before transplantation. For instance, successful $\mathrm{HCV}$ treatment has been associated with lower risk of PTDM ${ }^{50,51}$.

Obese patients obtain a clear benefit from kidney transplant compared with staying on dialysis ${ }^{52}$, but high body mass index (BMI) is associated with a higher risk of PTDM and worse patient and allograft outcomes ${ }^{53-55}$. Hence, many transplant centers exclude patients with high BMI from listing (BMI cutoff varies from 35 to $45 \mathrm{~kg} / \mathrm{m}^{2}$ between transplant centers ${ }^{56}$ ). Furthermore, a significant proportion of patients gain weight in the posttransplant period, likely because of the high doses of steroids and the liberalized $\operatorname{diet}^{57,58}$. Case series and small studies have reported promising results of bariatric surgery pre- and post-transplant ${ }^{59-65}$. Attention to the possibility of malabsorption induced by bariatric surgery (that is, Roux-en- $Y$ gastric bypass) is important because of an increased risk of urolithiasis, oxalate deposition in the kidney, and the potential (but not yet proven by proper, large pharmacokinetic studies) decreased absorption of immunosuppressive medications $\mathrm{s}^{61,64,66,67}$.
Changes in immunosuppression should be based on overall patient and allograft benefit rather than on the risk of PTDM development alone ${ }^{46}$. Although tacrolimus has a higher risk of PTDM compared with cyclosporine $\mathrm{A}^{42,68}$, the former is generally preferred because of the lower risk of rejection and higher graft survival ${ }^{69}$. The benefit of early corticosteroid withdrawal has been controversial; the largest randomized trial found no difference in PTDM development at 5 years post-transplant with corticosteroid maintenance versus early withdrawal ${ }^{70}$. This contrasts with the findings of an earlier meta-analysis that showed a reduced risk of PTDM with early steroid withdrawal but also an increased risk of allograft rejection ${ }^{71}$. When steroid withdrawal is chosen, the PTDM incidence is similar if steroids are given for 10 days versus an intraoperative bolus only, but the incidence of rejection is higher in the second group ${ }^{72}$. Another potential strategy to decrease the risk of PTDM would be to use CNI-free regimens. Use of belatacept, a T-cell co-stimulation blocker, reduces the risk of PTDM by $39 \%$ compared with $\mathrm{CNIs}^{73}$. Although mammalian target of rapamycin (mTOR) inhibitors are associated with a better glycemic profile than tacrolimus, they result in a worse lipid profile and higher rejection risk ${ }^{42}$.

Treatment of DM in the post-transplant period includes lifestyle modification with particular attention to healthy weight maintenance as well as pharmacologic therapy. Owing to the lack of evidence derived from well-designed prospective clinical trials investigating differences in hard clinical end points such as mortality, allograft loss, and CV events in this population, the optimal pharmacologic agent in transplant recipients is not well established ${ }^{42}$. In the early post-transplant period, it is recommended to treat hyperglycemia with insulin since it is the safest and most effective agent in the context of high corticosteroid doses ${ }^{46}$. Furthermore, this approach appears to reduce the odds of developing PTDM by $73 \%$ in the first year post-transplant ${ }^{74}$. After corticosteroid doses are reduced, treatment with oral anti-hyperglycemic agents is recommended, but the choice of specific agent should be individualized. Because of a lack of evidence, the most recent consensus recommendations were unable to propose a hierarchy of anti-hyperglycemic agents for PTDM ${ }^{46}$. The most commonly used anti-hyperglycemic medications post-transplant include metformin, sulfonylureas (that is, glipizide and glimepiride), and meglitinides (that is, repaglinide). Newer medications such as DPP-4 inhibitors (that is, sitagliptin, linagliptin, and vildagliptin) and GLP-1 agonists (exenatide and liraglutide) have been proposed for PTDM given their ability to counteract the effects of CNIs and corticosteroids by increasing glucose-dependent insulin secretion and inhibiting glucagon secretion ${ }^{75}$. In the general population, treatment with GLP-1 agonists decreases MACE ${ }^{76,77}$ but this has not yet been confirmed in the kidney transplant population. Although no long-term randomized trials of these agents using clinical end points have been carried out for PTDM, studies have demonstrated that they are safe and effective in controlling hyperglycemia in post-transplant patients ${ }^{78-84}$. Finally, SGLT-2 inhibitors (that is, empagliflozin, canagliflozin, and dapagliflozin) have been shown to be effective in the general population in controlling hyperglycemia, reducing proteinuria, slowing kidney function 
decline, promoting weight loss, decreasing blood pressure, and reducing $\mathrm{CV}$ risk $^{85-87}$. To date, only case reports and case series have reported the use of SGLT-2 inhibitors in the posttransplant period, and the biggest series of 25 patients has only been reported in abstract form ${ }^{88-90}$. These small series have shown that the effect of SGLT-2 inhibitors post-transplant is similar to the general population in terms of glucose control, weight loss, and decrease in blood pressure ${ }^{88-90}$. However, no long-term data are available, and no benefits in hard outcomes such as death, MACE, or graft failure rate have been demonstrated in kidney transplant recipients. Furthermore, some features of these medications, including the increased risk of genitourinary infections, volume depletion, ketoacidosis, and amputations, are particularly concerning for kidney transplant recipients ${ }^{85,86,91,92}$. Given the retrospective nature of the studies carried out to date in the post-transplant period with SGLT-2 inhibitors and the small number of patients included, we cannot reach a definitive conclusion on their safety profile ${ }^{88-90}$. A prospective interventional trial is ongoing (EMPTRA-DM) and we anxiously await the results $^{93}$.

\section{Cancer}

Solid organ transplant recipients have a twofold increased risk of cancer compared with the general population ${ }^{19}$. The standardized incidence ratios (SIRs) for infection-related malignancies-that is, Epstein-Barr virus (EBV)-associated lymphoma, Kaposi sarcoma (KS), hepatocellular carcinoma, genital and gastric cancers-are significantly elevated in kidney transplant recipients ${ }^{19,94}$. However, dozens of other cancer types unrelated to infection are also more common in the transplant population; the highest SIR is for the following cancers: squamous cell cancers of the skin and lip, renal cell carcinoma (RCC), cholangiocarcinoma, and salivary gland cancer ${ }^{19}$. Moreover, the incidence of lung and colorectal cancers, which are very common in the general population, is even higher in the transplant population $^{19,94}$. In contrast, the SIR of prostate and breast cancer is not higher in transplant recipients compared with the general population $^{19,94}$ (Table 3). Therefore, screening and preventative measures should be implemented in all transplant candidates and recipients. However, evidence to support a specific screening strategy is often lacking. A recent systematic review of clinical practice guidelines (CPGs) on cancer screening in solid organ transplant recipients highlights this point by demonstrating significant discrepancies across 13 CPGs (including eight CPGs specific to kidney transplant). Explanations for these differences include authors' interpretation of indirect data (that is, evidence of high incidence of a type of cancer but no evidence regarding the efficacy of the screening strategy) as well as lack of input from oncologists and public health and cancer screening experts ${ }^{95}$. Further research is needed to formulate evidence-based cancer screening guidelines for this high-risk population.

One of the most important risk factors for cancer development is tobacco use, but until recently there was only limited evidence regarding the benefits of smoking cessation. Opelz and Döhler ${ }^{96}$ found that the incidence of several cancers, most prominently lung cancer, significantly decreases with smoking cessation before transplant; however, incidences remain higher
Table 3. Incidence of cancer in solid organ transplant recipients as reported by Engels et al. ${ }^{19}$.

\begin{tabular}{|c|c|}
\hline Cancer site & $\begin{array}{l}\text { Standardized incidence } \\
\text { ratio }(95 \% \mathrm{Cl})\end{array}$ \\
\hline \multicolumn{2}{|l|}{ Infection-related malignancies } \\
\hline Non-Hodgkin lymphoma & $7.54(7.17-7.93)$ \\
\hline Liver & $11.56(10.83-12.33)$ \\
\hline Stomach & $1.67(1.42-1.96)$ \\
\hline Kaposi sarcoma & $61.46(50.95-73.49)$ \\
\hline Oropharynx & $2.01(1.64-2.43)$ \\
\hline Anus & $5.84(4.70-7.18)$ \\
\hline Hodgkin lymphoma & $3.58(2.86-4.43)$ \\
\hline Vulva & $7.60(5.77-9.83)$ \\
\hline Cervix & $1.03(0.75-1.38)$ \\
\hline Penis & $4.13(2.59-6.26)$ \\
\hline Nasopharynx & $0.96(0.42-1.90)$ \\
\hline Vagina & $2.35(0.94-4.84)$ \\
\hline \multicolumn{2}{|c|}{ Non-infection-related malignancies } \\
\hline Lung & $1.97(1.86-2.08)$ \\
\hline Prostate & $0.92(0.87-0.98)$ \\
\hline Kidney & $4.65(4.32-4.99)$ \\
\hline Colorectum & $1.24(1.15-1.34)$ \\
\hline Breast & $0.85(0.77-0.93)$ \\
\hline Melanoma & $2.38(2.14-2.63)$ \\
\hline Thyroid & $2.95(2.58-3.34)$ \\
\hline Urinary bladder & $1.52(1.33-1.73)$ \\
\hline $\begin{array}{l}\text { Skin (non-melanoma, non- } \\
\text { epithelial) }\end{array}$ & $13.85(11.92-16.00)$ \\
\hline Pancreas & $1.46(1.24-1.71)$ \\
\hline Lip & $16.78(14.02-19.92)$ \\
\hline Plasma cell neoplasm & $1.84(1.52-2.20)$ \\
\hline Acute myeloid leukemia & $3.01(2.45-3.65)$ \\
\hline Larynx & $1.59(1.29-1.95)$ \\
\hline Esophagus & $1.56(1.26-1.91)$ \\
\hline Uterine corpus & $0.86(0.70-1.05)$ \\
\hline Soft tissue, including heart & $2.25(1.74-2.87)$ \\
\hline Salivary gland & $4.55(3.44-5.91)$ \\
\hline Ovary & $0.95(0.72-1.24)$ \\
\hline Small intestine & $2.43(1.80-3.20)$ \\
\hline Brain & $0.76(0.55-1.01)$ \\
\hline Testis & $1.96(1.40-2.67)$ \\
\hline Intrahepatic bile duct & $5.76(4.08-7.91)$ \\
\hline Chronic myeloid leukemia & $3.47(2.46-4.77)$ \\
\hline Chronic lymphocytic leukemia & $0.59(0.38-0.89)$ \\
\hline Gallbladder & $2.00(1.25-3.02)$ \\
\hline Eye and orbit & $2.78(1.72-4.24)$ \\
\hline Renal pelvis & $2.05(1.20-3.29)$ \\
\hline Acute lymphocytic leukemia & $2.06(1.20-3.30)$ \\
\hline Mesothelioma & $1.30(0.73-2.15)$ \\
\hline Bones and joints & $1.98(1.09-3.33)$ \\
\hline Other acute leukemia & $2.20(0.71-5.13)$ \\
\hline Acute monocytic leukemia & $2.35(0.64-6.01)$ \\
\hline
\end{tabular}

$\mathrm{Cl}$, confidence interval. 
than in never-smokers. In the same study, smoking cessation before transplant also decreased the risk of graft loss and death ${ }^{96}$. Hence, it is strongly recommended to encourage smoking cessation at the time of kidney transplant candidacy evaluation.

Immunosuppression is a prominent risk factor for cancer development, but whether specific immunosuppressive agents confer higher risk than others is an area of active study. Azathioprine increases the risk of squamous cell carcinoma but not other types of skin cancer ${ }^{97,98}$, whereas mycophenolate may be protective ${ }^{98}$. Conflicting results have been obtained in studies comparing tacrolimus with cyclosporine in regard to the risk of malignancy ${ }^{99-104}$. Belatacept confers increased risk of post-transplant lymphoproliferative disorder, particularly in EBV-seronegative patients ${ }^{105-107}$. In regard to induction therapy, alemtuzumab increases the risk of non-Hodgkin lymphoma, other virus-related cancers, and colorectal and thyroid cancer ${ }^{99}$ whereas anti-lymphocyte globulin increases the risk of melanoma but surprisingly does not alter the risk of lymphomas ${ }^{99,108}$. Basiliximab did not increase the risk of cancers evaluated in this study $^{99}$.

mTOR inhibitors (that is, sirolimus and everolimus) suppress growth and proliferation in malignant cells ${ }^{109-111}$. Hence, mTOR inhibitor-based regimens have been used de novo to prevent cancer development in transplant patients with high cancer risk and conversion to an mTOR inhibitor-based regimen is often considered if cancer is diagnosed. Whereas a 2014 metaanalysis showed a decreased risk of malignancy by $40 \%$ (driven mainly by the decreased risk of non-melanoma skin cancer $)^{112}$, recent large studies have failed to show a difference in overall malignancy risk between patients on mTOR inhibitor-based immunosuppression and other regimens ${ }^{113-116}$. Some studies have not included non-melanoma skin cancer in their analysis, but most of the studies that did have found a decreased risk of non-melanoma skin cancer (particularly basal cell carcinoma) $)^{112,114,116-119}$. Nonetheless, mTOR inhibitor-based immunosuppression regimens have been associated with increased risk of mortality ${ }^{12,115}$ and post-transplant lymphoproliferative disorder $^{120,121}$. Therefore, it is not recommended to change to mTOR inhibitor-based regimens after a cancer diagnosis. The only situation in which conversion to mTOR inhibitor-based regimen is recommended is in transplant patients diagnosed with $\mathrm{KS}^{122}$ because of reports of complete regression of the KS lesion after conversion ${ }^{123-125}$.

Cancer immunotherapy is an emerging field requiring particular attention in kidney transplant recipients. Checkpoint inhibitors, which target the programmed cell death pathway (PD-1 and PD-L1) and the cytotoxic T-lymphocyte-associated antigen-4 (CTLA-4), are effective in the treatment of several types of cancers, including melanoma, RCC, and non-small cell lung cancer $^{126,127}$. However, case reports and series have reported a high risk of allograft rejection and loss with monoclonal antibodies against PD-1 but the incidence of this outcome is unknown $^{127-129}$. Conversely, this outcome is seen less frequently with agents targeting CTLA-4 ${ }^{127}$. A recent review found 17 reported solid organ transplant recipients (11 kidney, three liver, and three heart recipients) treated with these agents. One $(16 \%)$ of six patients treated with the CTLA-4 inhibitor ipilimumab had allograft rejection, compared with 5 (62\%) of 8 patients treated with PD-1 inhibitors, and $2(66 \%)$ of 3 patients treated with CTLA-4 followed by PD-1 inhibitors ${ }^{130}$. A similar pattern was seen in the subset of kidney transplant recipients alone ${ }^{130}$. Further research is necessary to clarify the safety and effectiveness of checkpoint inhibitors in transplant recipients and for development of regimens that minimize the risk of allograft rejection, such as combining these agents with mTOR, BRAF, mitogen-activated protein kinase (MEK), and Bruton's tyrosine kinase (BTK) inhibitors ${ }^{130}$.

\section{Infectious complications}

Infectious complications are common during the post-transplant period and account for $13 \%$ of overall mortality in kidney transplant recipients ${ }^{17}$. The degree of immunosuppression and epidemiological exposures are the main determinants of the risk of infections. Transplant infectious disease experts typically divide the post-transplant period into three roughly different intervals $^{131}$ :

(1) first month post-transplant, when infections are either a complication of the surgery/hospitalization or pre-existing in the donor or recipient;

(2) one to six months post-transplant; this is the period when immunosuppression is often the highest and opportunistic infections (Pneumocystis jirovecii pneumonia, CMV or other herpes virus infections, mycobacterial infections, and so on) often happen, warranting prophylactic measures to prevent such infections;

(3) after 6 to 12 months post-transplant, when immunosuppression is usually more stable and lower than in previous periods.

This timeline is obviously altered by heightened immunosuppression due to rejection episodes. During all of these periods, kidney transplant recipients are also at higher risk of "gardenvariety" infections such as community-acquired pneumonia, urinary tract infections, and so on.

In this article, we decided to focus on three particularly important subjects that either have changed dramatically in the last few years (that is, HCV) or warrant special attention in kidney transplant recipients (that is, $\mathrm{CMV}$ and $\mathrm{BK}$ virus), despite not being the most common infectious complications during the post-transplant period.

\section{Hepatitis $\mathrm{C}$ virus}

$\mathrm{HCV}$ infection is associated with higher incidences of CKD, faster progression to ESRD, and higher morbidity and mortality ${ }^{132-134}$. The prevalence of $\mathrm{HCV}$ in the ESRD population is significantly higher than in the general population, a finding which continues after transplantation ${ }^{135}$. HCV infection is associated with worse allograft outcomes (that is, allograft rejection, chronic allograft nephropathy and decreased graft survival), hepatic complications (that is, cirrhosis and hepatocellular carcinoma), 
PTDM, CV disease, de novo or recurrent glomerulonephritis, and overall worse patient survival ${ }^{136-141}$. Nevertheless, HCVinfected patients who receive a transplant have significantly lower morbidity and mortality than $\mathrm{HCV}$-infected patients who remain on the waiting list ${ }^{142-144}$.

Historically, treatment of $\mathrm{HCV}$ infection included interferon or pegylated interferon with or without ribavirin. Owing to a high rate of allograft rejection and loss, interferon is not recommended in transplant recipients ${ }^{145}$, and ribavirin causes hemolytic anemia in patients with low GFR ${ }^{146}$. The recent development of direct-acting antivirals (DAAs) has dramatically changed HCV treatment, making interferon and ribavirin treatment essentially obsolete. Several all-oral, interferon-free DAA regimens are highly effective and safe in CKD stages 4-5, ESRD, and kidney transplant populations with sustained virological response (SVR) rates of $90 \%$ to $100 \%{ }^{147-163}$. DAA treatment in kidney transplant recipients results in SVR rates ranging from $98 \%$ to $100 \%^{153-163}$. However, $36 \%$ of transplant patients require CNI dose adjustment, but no increased risk of acute rejection has been reported $^{153-163}$. Screening for hepatitis B virus (HBV) infection is recommended before starting $\mathrm{HCV}$ treatment given the risk for HBV reactivation with DAAs ${ }^{164}$.

The availability of HCV-positive deceased donor kidneys has increased dramatically as a result of the opioid epidemic in the USA. Moreover, the waiting time for an $\mathrm{HCV}$-positive kidney is much lower than for an HCV-negative kidney as these organs are currently not offered to HCV-negative transplant candidates ${ }^{157,158,165-167}$. This leads to two important questions: (1) Should HCV-positive candidates be treated with DAAs before or after kidney transplantation? (2) Is it safe to transplant $\mathrm{HCV}$-positive organs into HCV-negative recipients?

In terms of timing of $\mathrm{HCV}$ infection treatment, the most important factors to consider are DAA accessibility, the availability of $\mathrm{HCV}$-positive organs, and the waiting time reduction in the area where the patient would be transplanted. If using $\mathrm{HCV}$-infected donor kidneys results in a significant reduction in waiting time and DAAs are available, most patients would benefit from transplantation first followed by HCV treatment after transplantation. However, situations exist where treatment of HCV infection is indicated before transplant, including severe extrahepatic HCV manifestations such as mixed cryoglobulinemia syndrome, compensated cirrhosis with high risk of liver disease progression, and a living donor available only after 24 weeks (where there is no benefit of delaying the 12-week treatment and 12-week post-treatment monitoring for SVR) ${ }^{135}$.

Two trials evaluating the safety of transplanting HCV-positive organs to HCV-negative recipients have been published recently. In the THINKER (Transplanting Hepatitis $\mathrm{C}$ kidneys Into Negative Kidney Recipients) trial ${ }^{166,168}, 20 \mathrm{HCV}$-negative patients have been transplanted with $\mathrm{HCV}$-infected kidneys followed by initiation of elbasvir/grazoprevir on post-transplant day 3. All recipients developed a positive $\mathrm{HCV}$ viral load post-transplant, but within 4 weeks of treatment the virus was undetectable, and
$100 \%$ of patients achieved SVR at 12 weeks $^{166,168}$. At 1 year of follow-up, allograft function, blood pressure, and proteinuria were excellent ${ }^{155}$. Another $10 \mathrm{HCV}$-negative recipients have been transplanted with HCV-positive kidneys in the EXPANDER-1 (Exploring Renal Transplants Using Hepatitis C Infected Donors for HCV-Negative Recipients) trial in which elbasvir/ grazoprevir was started immediately before transplantation. Only three patients had detectable HCV RNA early post-transplant, and $100 \%$ had negative HCV viral load at 12 weeks ${ }^{169,170}$. Both trials showed a good safety profile of elbasvir/grazoprevir early post-transplant and good early allograft outcomes ${ }^{166,168-170}$. Currently, this practice is recommended in the controlled setting of clinical trials only, but if the results of the THINKER and EXPANDER-1 trials are confirmed in larger studies, it might become a widespread practice that would expand the donor pool.

\section{Cytomegalovirus}

CMV remains a frequent infectious complication after kidney transplantation. Active CMV infection can lead to a viral syndrome (CMV syndrome) or tissue-invasive disease-including colitis, pneumonitis, nephritis, hepatitis, encephalitis, and retinitis-or both. Furthermore, CMV infection has "indirect effects", including increased risk of allograft failure ${ }^{131,171}$

The most important risk factor is CMV serostatus in the donor and recipient, and the highest risk is in the CMV IgG-negative recipient transplanted with a CMV IgG-positive organ ${ }^{172}$. Another risk factor is level and type of immunosuppression; incidence is higher in patients induced with lymphocytedepleting agents (that is, thymoglobulin), and incidence is lower with mTOR inhibitor-based chronic immunosuppression regimens ${ }^{173-179}$.

CMV prevention strategies are commonly used post-transplant. The main approaches are universal prophylaxis or pre-emptive therapy. Universal prophylaxis entails administration of antiviral drugs (most commonly valganciclovir) to all patients or those at higher risk of CMV infection starting the first 10 days post-transplant and continuing for 3 to 6 months. Treatment duration is guided by the specific CMV status of donor and recipient. This approach is easier to implement and prevents early CMV infection; however, late CMV infection is more common with this approach, drug costs may be high, and patients often experience drug-induced adverse events, including leukopenia and hepatitis, among others ${ }^{172}$. Pre-emptive therapy involves CMV viral load monitoring at regular intervals (most often weekly), and therapy is started only when a specific viral load threshold is crossed. Because of the variability of the tests, no universal threshold to initiate therapy has been defined ${ }^{180,181}$. This approach eliminates the possibility of drug side effects and prevents late CMV infection better, but early CMV infection is more frequent. Moreover, this approach may be more difficult to implement and the costs of frequent monitoring might also be high ${ }^{172}$. A randomized trial comparing both approaches found no difference in the incidence of CMV disease ${ }^{182}$. The role of 
screening for CMV viremia later after transplantation is not well established.

Treatment of CMV syndrome or tissue-invasive disease consists of oral valganciclovir or intravenous ganciclovir. In the Study of Valcyte Compared to Ganciclovir in Patients with Cytomegalovirus Disease who are Solid Organ Transplant Recipients (VICTOR trial) ${ }^{183}, 321$ solid organ transplant patients (>70\% kidney transplant recipients) with CMV viremia, CMV syndrome, or CMV disease were randomly assigned to ganciclovir or valganciclovir. Viremia eradication and treatment success were similar in the two groups. Nevertheless, international consensus guidelines still recommend intravenous ganciclovir as the initial treatment for patients with life-threatening CMV infection $^{172}$. Reduction of the intensity of immunosuppression is also associated with higher CMV eradication rates ${ }^{184}$.

Drug resistance needs to be suspected when there is persistent CMV viremia or disease despite prolonged antiviral therapy (6 or more weeks of cumulative drug exposure or more than 2 weeks of ongoing full-dose therapy) ${ }^{172}$. Genotypic assays to detect mutations are used to test for resistance. In $90 \%$ of patients, mutation of the UL97 kinase gene appears first with varying degrees of resistance to ganciclovir but does not confer cidofovir or foscarnet resistance. UL54 mutations evolve later, conferring increased ganciclovir resistance and possibly cidofovir or foscarnet resistance or both. Depending on the mutation encountered, treatment with high doses of ganciclovir, foscarnet, or cidofovir could be indicated, but no controlled trials have defined the best intervention in these cases ${ }^{172}$.

\section{BK virus}

$\mathrm{BK}$ virus is a polyomavirus that is highly seroprevalent in humans but causes disease only in immunocompromised patients. Following kidney transplantation, BK virus causes tubulointerstitial nephritis in $1 \%$ to $10 \%$ of patients ${ }^{185-188}$. The most important risk factor for BK virus nephropathy development is the level of immunosuppression, but recent studies have demonstrated the importance of BK virus-specific T-cell functionality ${ }^{189,190}$ and $\mathrm{BK}$ virus seroprevalence in donors and recipients, and risk is higher in those donor-positive/recipientnegative pairs ${ }^{191,192}$. Antibody-depleting induction therapy increases the risk of $\mathrm{BK}$ virus nephropathy, whereas mTOR inhibitor reduces the risk ${ }^{193}$.
Screening of BK virus nephritis relies on testing for viral replication in urine and blood. Viral replication in urine is tested with urine cytology looking for decoy cells or by polymerase chain reaction (PCR), whereas plasma or whole blood viral replication is confirmed by PCR. In general, the correlation with BK virus-associated nephropathy is higher for viremia (positive BK PCR in blood), lower for viruria (positive BK PCR in urine), and lowest for urine cytology (Table 4) ${ }^{185,194-198}$. The KDIGO guidelines on kidney transplant recipients recommend urine or blood PCR monthly for the first 3 to 6 months posttransplant and then every 3 months until the end of the first post-transplant year ${ }^{122}$. However, other international consensus guidelines suggest continuing screening every 3 months until the end of the second year post-transplant and yearly thereafter ${ }^{186,199}$. Definitive diagnosis is made with histology on kidney allograft biopsy showing tubulointerstitial nephritis with cytopathic changes and positive immunohistochemistry for $\mathrm{SV} 40^{131}$.

The cornerstone of therapy is reduction of immunosuppression ${ }^{121}$. However, the specific strategy of immunosuppression reduction is not well stablished and is mainly center-specific. A common practice is withdrawal of the antimetabolite drug (usually mycophenolate) and decrease of CNI dosing by 50\%. Alternative approaches have been to stop tacrolimus and initiate either cyclosporine or an mTOR inhibitor. However, the evidence to support any of these approaches is $l^{20 w^{200-204}}$. Some agents with antiviral properties have been suggested. Adding cidofovir or leflunomide does not increase graft survival ${ }^{205}$. Treatment with intravenous immunoglobulin (IVIG) is promising based on the fact that many formulations of IVIG have neutralizing BK antibodies ${ }^{206}$ and several case series have described its efficacy ${ }^{207,208}$, but large randomized controlled trials are needed before its widespread use can be recommended. Although quinolones have been reported to have anti-BK properties, randomized trials have shown no benefit of adding levofloxacin ${ }^{209,210}$.

\section{Conclusions}

Kidney transplant recipients have a high risk of complications due to adverse events of potent immunosuppressive medications and their pre- and post-transplant complex medical history. It is important for the clinician taking care of these patients to be aware of the most common complications encountered in the post-transplant period and how to screen, diagnose, and treat

Table 4. Non-invasive diagnostic tests for BK virus-associated nephropathy.

\begin{tabular}{|c|c|c|c|c|c|}
\hline Test & Threshold value & Sensitivity & Specificity & PPV & NPV \\
\hline Decoy cells ${ }^{185,194-197}$ & $>10$ cells/cytospin & $25-100 \%$ & $71-96 \%$ & $5-57 \%$ & $97-100 \%$ \\
\hline Urine BK PCR ${ }^{197,198}$ & $>1 \times 10^{7}$ copies $/ \mathrm{mL}$ & $100 \%$ & $92-96 \%$ & $31-67 \%$ & $100 \%$ \\
\hline Blood/plasma BK PCR $185,195,197,198$ & $>1 \times 10^{4}$ copies $/ \mathrm{mL}$ & $100 \%$ & $88-96 \%$ & $50-82 \%$ & $100 \%$ \\
\hline
\end{tabular}

NPV, negative predictive value; PCR, polymerase chain reaction; PPV, positive predictive value. 
them. A multidisciplinary team approach is often required given the multiple complications that fall into different medical and surgical specialties in kidney transplant recipients.
Grant information

The author(s) declared that no grants were involved in supporting this work.
1. United Stated Renal Data System: 2017 USRDS annual data report: Epidemiology of kidney disease in the United States. National Institutes of Health, National Institute of Diabetes and Digestive and Kidney Diseases, Bethesda, MD. 2017. Reference Source

2. Nakano T, Ninomiya T, Sumiyoshi S, et al.: Association of kidney function with coronary atherosclerosis and calcification in autopsy samples from Japanese elders: the Hisayama study. Am J Kidney Dis. 2010; 55(1): 21-30. PubMed Abstract | Publisher Full Text

3. Chonchol M, Whittle J, Desbien A, et al:: Chronic kidney disease is associated with angiographic coronary artery disease. Am J Nephrol. 2008; 28(2): 354-60. PubMed Abstract | Publisher Full Text

4. Ramphul R, Fernandez M, Firoozi S, et al:: Assessing cardiovascular risk in chronic kidney disease patients prior to kidney transplantation: clinical usefulness of a standardised cardiovascular assessment protocol. $B M C$ Nephrol. 2018; 19(1): 2

PubMed Abstract | Publisher Full Text | Free Full Text

5. Lentine KL, Costa SP, Weir MR, et al:: Cardiac disease evaluation and management among kidney and liver transplantation candidates: a scientific statement from the American Heart Association and the American College of Cardiology Foundation. J Am Coll Cardiol. 2012; 60(5): 434-80. PubMed Abstract | Publisher Full Text

6. Lentine $\mathrm{KL}$, Brennan DC, Schnitzler MA: Incidence and predictors of myocardial infarction after kidney transplantation. J Am Soc Nephrol. 2005; 16(2): 496-506. PubMed Abstract | Publisher Full Text

7. Kasiske BL, Maclean JR, Snyder JJ: Acute myocardial infarction and kidney transplantation. J Am Soc Nephrol. 2006; 17(3): 900-7. PubMed Abstract | Publisher Full Text

8. Rao NN, Coates PT: Cardiovascular Disease After Kidney Transplant. Semin Nephrol. 2018; 38(3): 291-7. PubMed Abstract | Publisher Full Text

9. $\quad F$ Weiner DE, Park M, Tighiouart $\mathrm{H}$, et al:: Albuminuria and Allograft Failure Cardiovascular Disease Events, and All-Cause Death in Stable Kidney Transplant Recipients: A Cohort Analysis of the FAVORIT Trial. Am J Kidney Dis. 2019; 73(1): 51-61.

PubMed Abstract | Publisher Full Text | Free Full Text | F1000 Recommendation

10. Naesens $M$, Heylen $L$, Lerut $E$, et al.: Intrarenal resistive index after renal transplantation. N Engl J Med. 2013; 369(19): 1797-806. PubMed Abstract | Publisher Full Text

11. Alhamad T, Brennan DC, Brifkani Z, et al.: Pretransplant Midodrine Use: A Newly Identified Risk Marker for Complications After Kidney Transplantation. Transplantation. 2016; 100(5): 1086-93. PubMed Abstract | Publisher Full Text | Free Full Text

12. F Pottebaum AA, Hagopian JC, Brennan DC, et al.: Influence of pretransplant midodrine use on outcomes after kidney transplantation. Clin Transplant. 2018; 32(9): e13366.

PubMed Abstract | Publisher Full Text | F1000 Recommendation

13. Wanner C, Tonelli M, Kidney Disease: Improving Global Outcomes Lipid Guideline Development Work Group Members: KDIGO Clinical Practice Guideline for Lipid Management in CKD: summary of recommendation statements and clinical approach to the patient. Kidney Int. 2014; 85(6): 1303-9. PubMed Abstract | Publisher Full Text

14. Holdaas H, Fellström B, Jardine AG, et al.: Effect of fluvastatin on cardiac outcomes in renal transplant recipients: a multicentre, randomised, placebocontrolled trial. Lancet. 2003; 361(9374): 2024-31. PubMed Abstract | Publisher Full Text

15. Holdaas $\mathrm{H}$, Fellström B, Cole E, et al.: Long-term cardiac outcomes in renal transplant recipients receiving fluvastatin: the ALERT extension study. Am J Transplant. 2005; 5(12): 2929-36.

PubMed Abstract | Publisher Full Text

16. Hart A, Smith JM, Skeans MA, et al.: OPTN/SRTR 2016 Annual Data Report: Kidney. Am J Transplant. 2018; 18 Suppl 1: 18-113.

PubMed Abstract | Publisher Full Text | Free Full Text

17. (ANZDATA) ANZDaTR: 41st Annual ANZDATA Report. 2018. Reference Source

18. Kasiske BL, Snyder JJ, Gilbertson D, et al: Diabetes mellitus after kidney transplantation in the United States. Am J Transplant. 2003; 3(2): 178-85. PubMed Abstract | Publisher Full Text

19. $F$ Engels EA, Pfeiffer RM, Fraumeni JF Jr, et al: Spectrum of cancer risk among US solid organ transplant recipients. JAMA. 2011; 306(17): 1891-901. PubMed Abstract | Publisher Full Text | Free Full Text | F1000 Recommendation

20. Knoll GA, Fergusson D, Chassé M, et al:: Ramipril versus placebo in kidney transplant patients with proteinuria: a multicentre, double-blind, randomised controlled trial. Lancet Diabetes Endocrinol. 2016; 4(4): 318-26.

PubMed Abstract | Publisher Full Text

21. Opelz G, Döhler B: Cardiovascular death in kidney recipients treated with reninangiotensin system blockers. Transplantation. 2014; 97(3): 310-5. PubMed Abstract

22. F Hiremath S, Fergusson DA, Fergusson N, et al.: Renin-Angiotensin System Blockade and Long-term Clinical Outcomes in Kidney Transplant Recipients: A Meta-analysis of Randomized Controlled Trials. Am J Kidney Dis. 2017; 69(1): $78-86$.

PubMed Abstract | Publisher Full Text | F1000 Recommendation

23. European Renal Best Practice Transplantation Guideline Development Group: ERBP Guideline on the Management and Evaluation of the Kidney Donor and Recipient. Nephrol Dial Transplant. 2013; 28 Suppl 2: ii1-71.

PubMed Abstract | Publisher Full Text

24. Dudley C, Harden P: Renal Association Clinical Practice Guideline on the assessment of the potential kidney transplant recipient. Nephron Clin Pract. 2011; 118 Suppl 1: c209-c224.

PubMed Abstract | Publisher Full Text

25. Kälble T, Lucan M, Nicita G, et al.: EAU guidelines on renal transplantation. Eur Urol. 2005; 47(2): 156-66.

PubMed Abstract | Publisher Full Text

26. Kasiske BL, Cangro CB, Hariharan S, et al:: The evaluation of renal transplantation candidates: clinical practice guidelines. Am J Transplant. 2001 1 Suppl 2: 3-95.

PubMed Abstract | Publisher Full Text

27. John R, Lietz K, Huddleston S, et al.: Perioperative outcomes of cardiac surgery in kidney and kidney-pancreas transplant recipients. J Thorac Cardiovasc Surg. 2007; 133(5): 1212-9.

PubMed Abstract | Publisher Full Tex

28. Zhang L, Garcia JM, Hill PC, et al:: Cardiac surgery in renal transplant recipients: experience from Washington Hospital Center. Ann Thorac Surg. 2006; 81(4): 1379-84.

PubMed Abstract | Publisher Full Text

29. Mitruka SN, Griffith BP, Kormos RL, et al.: Cardiac operations in solid-organ transplant recipients. Ann Thorac Surg. 1997; 64(5): 1270-8. PubMed Abstract | Publisher Full Text

30. Massad MG, Kpodonu J, Lee J, et al.: Outcome of coronary artery bypass operations in patients with renal insufficiency with and without renal transplantation. Chest. 2005; 128(2): 855-62. PubMed Abstract | Publisher Full Text

31. Wang LW, Fahim MA, Hayen A, et al:: Cardiac testing for coronary artery disease in potential kidney transplant recipients. Cochrane Database Syst Rev. 2011; (12): CD008691. PubMed Abstract | Publisher Full Text

32. Wang LW, Masson P, Turner RM, et al.: Prognostic value of cardiac tests in potential kidney transplant recipients: a systematic review. Transplantation. 2015; 99(4): 731-45.

PubMed Abstract | Publisher Full Text

33. Rosário MA, Lima JJ, Parga JR, et al.: [Coronary calcium score as predictor of stenosis and events in pretransplant renal chronic failure]. Arq Bras Cardiol. 2010; 94(2): 236-43, 252-60, 239-47. PubMed Abstract | Publisher Full Text

34. Winther S, Bøttcher M, Jørgensen HS, et al.: Coronary Calcium Score May Replace Cardiovascular Risk Factors as Primary Risk Stratification Tool Before Kidney Transplantation. Transplantation. 2016; 100(10): 2177-87. PubMed Abstract | Publisher Full Text

35. Haydar AA, Hujairi NM, Covic AA, et al.: Coronary artery calcification is related to coronary atherosclerosis in chronic renal disease patients: a study comparing EBCT-generated coronary artery calcium scores and coronary angiography. Nephrol Dial Transplant. 2004; 19(9): 2307-12. PubMed Abstract | Publisher Full Text

36. Sharples EJ, Pereira D, Summers S, et al:: Coronary artery calcification measured with electron-beam computerized tomography correlates poorly with coronary artery angiography in dialysis patients. Am J Kidney Dis. 2004; 43(2): 313-9. PubMed Abstract | Publisher Full Text 
37. Moody WE, Lin EL, Stoodley M, et al.: Prognostic Utility of Calcium Scoring as an Adjunct to Stress Myocardial Perfusion Scintigraphy in End-Stage Renal Disease. Am J Cardiol. 2016; 117(9): 1387-96. PubMed Abstract | Publisher Full Text | Free Full Text

38. F Winther S, Svensson M, Jørgensen HS, et al:: Prognostic Value of Risk Factors, Calcium Score, Coronary CTA, Myocardial Perfusion Imaging, and Invasive Coronary Angiography in Kidney Transplantation Candidates. JACC Cardiovasc Imaging. 2018; 11(6): 842-54.

PubMed Abstract | Publisher Full Text | F1000 Recommendation

39. lio K, Nagasawa Y, Kimura T, et al.: Assessment of coronary stenosis by a 16-slice MDCT scanner in asymptomatic diabetic patients starting dialysis therapy. Nephron Clin Pract. 2008; 109(2): c72-c79.

PubMed Abstract | Publisher Full Text

40. de Bie MK, Buiten MS, Gaasbeek A, et al:: CT coronary angiography is feasible for the assessment of coronary artery disease in chronic dialysis patients, despite high average calcium scores. PLoS One. 2013; 8(7): e67936. PubMed Abstract | Publisher Full Text | Free Full Text

41. Arner P, Gunnarsson R, Blomdahl S, et al:: Some characteristics of steroid diabetes: a study in renal-transplant recipients receiving high-dose corticosteroid therapy. Diabetes Care. 1983; 6(1): 23-5. PubMed Abstract | Publisher Full Text

42. Sharif A, Cohney S: Post-transplantation diabetes-state of the art. Lancet Diabetes Endocrinol. 2016; 4(4): 337-49.

PubMed Abstract | Publisher Full Tex

43. Revanur VK, Jardine AG, Kingsmore DB, et al: Influence of diabetes mellitus on patient and graft survival in recipients of kidney transplantation. Clin Transplant. 2001; 15(2): 89-94.

PubMed Abstract | Publisher Full Text

44. Hjelmesaeth J, Hartmann A, Leivestad T, et al:: The impact of early-diagnosed new-onset post-transplantation diabetes mellitus on survival and major cardiac events. Kidney Int. 2006; 69(3): 588-95.

PubMed Abstract | Publisher Full Text

45. Cosio FG, Pesavento TE, Kim S, et al:: Patient survival after renal

transplantation: IV. Impact of post-transplant diabetes. Kidney Int. 2002; 62(4): $1440-6$.

PubMed Abstract | Publisher Full Text

46. Sharif A, Hecking M, de Vries AP, et al:: Proceedings from an international consensus meeting on posttransplantation diabetes mellitus: recommendations and future directions. Am J Transplant. 2014; 14(9): 1992-2000.

PubMed Abstract | Publisher Full Text | Free Full Text

47. Huang JW, Famure O, Li Y, et al:: Hypomagnesemia and the Risk of New-Onse Diabetes Mellitus after Kidney Transplantation. J Am Soc Nephrol. 2016; 27(6): 1793-800.

PubMed Abstract | Publisher Full Text | Free Full Text

48. Hjelmesaeth J, Sagedal S, Hartmann A, et al:: Asymptomatic cytomegalovirus infection is associated with increased risk of new-onset diabetes mellitus and impaired insulin release after renal transplantation. Diabetologia. 2004; 47(9): 1550-6.

PubMed Abstract | Publisher Full Text

49. Garg N, Weinberg J, Ghai S, et al:: Lower magnesium level associated with newonset diabetes and pre-diabetes after kidney transplantation. J Nephrol. 2014; 27(3): 339-44.

PubMed Abstract | Publisher Full Text

50. Kamar N: Evidence that clearance of hepatitis $\mathbf{C}$ virus RNA after alphainterferon therapy in dialysis patients is sustained after renal transplantation. $J$ Am Soc Nephrol. 2003; 14(8): 2092-8.

PubMed Abstract | Publisher Full Text

51. Gürsoy M, Güvener N, Köksal R, et al:: Impact of HCV infection on development of posttransplantation diabetes mellitus in renal allograft recipients. Transplant Proc. 2000; 32(3): 561-2.

PubMed Abstract | Publisher Full Text

52. Krishnan N, Higgins R, Short A, et al:: Kidney Transplantation Significantly Improves Patient and Graft Survival Irrespective of BMI: A Cohort Study. Am Transplant. 2015; 15(9): 2378-86.

PubMed Abstract | Publisher Full Text

53. Naik AS, Sakhuja A, Cibrik DM, et al:: The Impact of Obesity on Allograft Failure After Kidney Transplantation: A Competing Risks Analysis. Transplantation. 2016; 100(9): 1963-9.

PubMed Abstract | Publisher Full Tex

54. Hill CJ, Courtney AE, Cardwell CR, et al.: Recipient obesity and outcomes after kidney transplantation: a systematic review and meta-analysis. Nephrol Dial Transplant. 2015; 30(8): 1403-11.

PubMed Abstract | Publisher Full Text

55. Sood A, Hakim DN, Hakim NS: Consequences of Recipient Obesity on Postoperative Outcomes in a Renal Transplant: A Systematic Review and Meta-Analysis. Exp Clin Transplant. 2016; 14(2): 121-8. PubMed Abstract | Publisher Full Text

56. Lentine $\mathrm{KL}$, Delos Santos $\mathrm{R}$, Axelrod $\mathrm{D}$, et al.: Obesity and kidney transplant candidates: how big is too big for transplantation? Am J Nephrol. 2012; 36(6): $575-86$.

PubMed Abstract | Publisher Full Text

57. Johnson CP, Gallagher-Lepak S, Zhu YR, et al:: Factors influencing weight gain after renal transplantation. Transplantation. 1993; 56(4): 822-7. PubMed Abstract | Publisher Full Text
58. Clunk JM, Lin CY, Curtis JJ: Variables affecting weight gain in renal transplant recipients. Am J Kidney Dis. 2001; 38(2): 349-53. PubMed Abstract | Publisher Full Text

59. Freeman $\mathrm{CM}$, Woodle ES, Shi J, et al.: Addressing morbid obesity as a barrier to renal transplantation with laparoscopic sleeve gastrectomy. Am J Transplant. 2015; 15(5): 1360-8.

PubMed Abstract | Publisher Full Text

60. F Kim Y, Jung AD, Dhar VK, et al:: Laparoscopic sleeve gastrectomy improves renal transplant candidacy and posttransplant outcomes in morbidly obese patients. Am J Transplant. 2018; 18(2): 410-6. patients. Am J Transplant. 2018; 18(2): 410-6. PubMed Abstract | Publisher Full Text | F1000 Recommendation

61. F Thomas IA, Gaynor JJ, Joseph T, et al:: Roux-en-Y gastric bypass is an effective bridge to kidney transplantation: Results from a single center. Clin Transplant. 2018; 32(5): e13232.

PubMed Abstract | Publisher Full Text | F1000 Recommendation

62. Alexander JW, Goodman HR, Gersin K, et al:: Gastric bypass in morbidly obese patients with chronic renal failure and kidney transplant. Transplantation. 2004; 78(3): 469-74

PubMed Abstract | Publisher Full Text

63. Modanlou KA, Muthyala $\mathrm{U}$, Xiao $\mathrm{H}$, et al:: Bariatric surgery among kidney transplant candidates and recipients: analysis of the United States renal data system and literature review. Transplantation. 2009; 87(8): 1167-73.

PubMed Abstract | Publisher Full Text | Free Full Text

64. Szomstein S, Rojas R, Rosenthal RJ: Outcomes of laparoscopic bariatric surgery after renal transplant. Obes Surg. 2010; 20(3): 383-5. PubMed Abstract | Publisher Full Text

65. Golomb I, Winkler J, Ben-Yakov A, et al: Laparoscopic sleeve gastrectomy as a weight reduction strategy in obese patients after kidney transplantation. Am J Transplant. 2014; 14(10): 2384-90. PubMed Abstract | Publisher Full Tex

66. Arias RH, Mesa L, Posada JG, et al:: Kidney transplantation and gastric bypass: better control of comorbidities. Obes Surg. 2010; 20(7): 851-4. PublMed Abstract | Publisher Full Text

67. Rogers CC, Alloway RR, Alexander JW, et al:: Pharmacokinetics of mycophenolic acid, tacrolimus and sirolimus after gastric bypass surgery in end-stage renal disease and transplant patients: a pilot study. Clin Transplant. 2008; 22 (3): 281-91.

PubMed Abstract | Publisher Full Text | Free Full Text

68. F Wissing KM, Abramowicz D, Weekers $L$, et al:: Prospective randomized study of conversion from tacrolimus to cyclosporine $A$ to improve glucose metabolism in patients with posttransplant diabetes mellitus after renal transplantation. Am J Transplant. 2018; 18(7): 1726-34.

PubMed Abstract | Publisher Full Text | F1000 Recommendation

69. Ekberg $\mathrm{H}$, Tedesco-Silva $\mathrm{H}$, Demirbas $\mathrm{A}$, et al.: Reduced exposure to calcineurin inhibitors in renal transplantation. N Engl J Med. 2007; 357(25): 2562-75. PubMed Abstract | Publisher Full Text

70. Pirsch JD, Henning AK, First MR, et al: New-Onset Diabetes After Transplantation: Results From a Double-Blind Early Corticosteroid Withdrawal Trial. Am J Transplant. 2015; 15(7): 1982-90. PubMed Abstract | Publisher Full Text

71. Knight SR, Morris PJ: Steroid avoidance or withdrawal after renal transplantation increases the risk of acute rejection but decrease cardiovascular risk. A meta-analysis. Transplantation. 2010; 89(1): 1-14. PubMed Abstract | Publisher Full Text

72. F Mourad G, Glyda M, Albano L, et al.: Incidence of Posttransplantation Diabetes Mellitus in De Novo Kidney Transplant Recipients Receiving Prolonged-Release Tacrolimus-Based Immunosuppression With 2 Different Corticosteroid Minimization Strategies: ADVANCE, A Randomized Controlled Trial. Transplantation. 2017; 101(8): 1924-34.

PubMed Abstract | Publisher Full Text | Free Full Text | F1000 Recommendation

73. $F$ Masson $P$, Henderson L, Chapman JR, et al:: Belatacept for kidney transplant recipients. Cochrane Database Syst Rev. 2014 (11): CD010699. PubMed Abstract | Publisher Full Text | F1000 Recommendation

74. Hecking M, Haidinger M, Döller D, et al.: Early basal insulin therapy decreases new-onset diabetes after renal transplantation. J Am Soc Nephrol. 2012; 23(4): 739-49.

PubMed Abstract | Publisher Full Text | Free Full Text

75. Sadhu AR, Schwartz SS, Herman ME: THE RATIONALE FOR USE OF INCRETINS IN THE MANAGEMENT OF NEW ONSET DIABETES AFTER TRANSPLANTATION (NODAT). Endocr Pract. 2015; 21(7): 814-22. PubMed Abstract | Publisher Full Text

76. F Marso SP, Daniels GH, Brown-Frandsen K, et al:: Liraglutide and Cardiovascular Outcomes in Type 2 Diabetes. N Engl J Med. 2016; 375(4): $311-22$

PubMed Abstract | Publisher Full Text | Free Full Text | F1000 Recommendation

77. $\quad F$ Marso SP, Bain SC, Consoli A, et al:: Semaglutide and Cardiovascular Outcomes in Patients with Type 2 Diabetes. N Engl J Med. 2016; 375(19): 1834-44. PubMed Abstract | Publisher Full Text | F1000 Recommendation

78. Haidinger M, Werzowa J, Hecking M, et al.: Efficacy and safety of vildagliptin in new-onset diabetes after kidney transplantation--a randomized, double-blind, placebo-controlled trial. Am J Transplant. 2014; 14(1): 115-23.

PubMed Abstract | Publisher Full Tex 
79. Werzowa J, Hecking $\mathrm{M}$, Haidinger $\mathrm{M}$, et al.: Vildagliptin and pioglitazone in patients with impaired glucose tolerance after kidney transplantation: a randomized, placebo-controlled clinical trial. Transplantation. 2013; 95(3): $456-62$.

PubMed Abstract | Publisher Full Text

80. Boerner BP, Miles CD, Shivaswamy V: Efficacy and safety of sitagliptin for the treatment of new-onset diabetes after renal transplantation. Int $J$ Endocrinol. 2014; 2014: 617638.

PubMed Abstract | Publisher Full Text | Free Full Text

81. Strom Halden TA, Asberg A, Vik K, et al:: Short-term efficacy and safety of sitagliptin treatment in long-term stable renal recipients with new-onset diabetes after transplantation. Nephrol Dial Transplant. 2014; 29(4): 926-33. PubMed Abstract | Publisher Full Text

82. Pinelli NR, Patel A, Salinitri FD: Coadministration of liraglutide with tacrolimus in kidney transplant recipients: a case series. Diabetes Care. 2013; 36(10): e171-2.

PubMed Abstract | Publisher Full Text | Free Full Text

83. Krisl J, Gaber A, Sadhu A: Long-Acting Glucagon-Like Peptide-1 (GLP-1) Agonist Therapy in Post Solid Organ Transplant Patients. Transplantation. 2014 98: 523-4.

Publisher Full Text

84. Lane JT, Odegaard DE, Haire CE, et al:: Sitagliptin therapy in kidney transplant recipients with new-onset diabetes after transplantation. Transplantation. 2011 92(10): e56-7.

PubMed Abstract | Publisher Full Text

85. F Zinman B, Wanner C, Lachin JM, et al:: Empagliflozin, Cardiovascular Outcomes, and Mortality in Type 2 Diabetes. N Engl J Med. 2015; 373(22): 2117-28.

PubMed Abstract | Publisher Full Text | F1000 Recommendation

86. F Neal B, Perkovic V, Mahaffey KW, et al:: Canagliflozin and Cardiovascular and Renal Events in Type 2 Diabetes. N Engl J Med. 2017; 377(7): 644-57. PubMed Abstract | Publisher Full Text | F1000 Recommendation

87. Heerspink HJ, Perkins BA, Fitchett DH, et al:: Sodium Glucose Cotransporter 2 Inhibitors in the Treatment of Diabetes Mellitus: Cardiovascular and Kidney Effects, Potential Mechanisms, and Clinical Applications. Circulation. 2016; 134(10): 752-72. PubMed Abstract | Publisher Full Text

88. F Beshyah SA, Beshyah AS, Beshyah WS, et al:: Use of SGLT2 Inhibitors in Diabetic Renal Transplant Recipients: A Mixed Method Exploratory Exercise. Int J Diabetes Metab. 2018; 24: 16-21.

Publisher Full Text | F1000 Recommendation

89. F Rajasekeran H, Kim SJ, Cardella CJ, et al:: Use of Canagliflozin in Kidney Transplant Recipients for the Treatment of Type 2 Diabetes: A Case Series. Diabetes Care. 2017; 40(7): e75-e76.

PubMed Abstract | Publisher Full Text | F1000 Recommendation

90. Kwon HY, Kong JM: Sodium/Glucose Cotransporter 2 (SGLT2) Inhibitor for Diabetic Kidney Transplant (KT) Patients. Kidney Week 2017, American Society of Nephrology. New Orleans, LA USA, 2017.

Reference Source

91. Handelsman $\mathrm{Y}$, Henry RR, Bloomgarden ZT, et al.: AMERICAN ASSOCIATION OF CLINICAL ENDOCRINOLOGISTS AND AMERICAN COLLEGE OF ENDOCRINOLOGY POSITION STATEMENT ON THE ASSOCIATION OF SGLT-2 INHIBITORS AND DIABETIC KETOACIDOSIS. Endocr Pract. 2016; 22(6): 753-62. PubMed Abstract | Publisher Full Text

92. F Chang HY, Singh S, Mansour O, et al.: Association Between SodiumGlucose Cotransporter 2 Inhibitors and Lower Extremity Amputation Among Patients With Type 2 Diabetes. JAMA Intern Med. 2018; 178(9): 1190-8. PubMed Abstract | Publisher Full Text | Free Full Text | F1000 Recommendation

93. Empagliflozin in Post-Transplantation Diabetes Mellitus (EMPTRA-DM). Reference Source

94. F Grulich AE, van Leeuwen MT, Falster MO, et al:: Incidence of cancers in people with HIV/AIDS compared with immunosuppressed transplant recipients: a meta-analysis. Lancet. 2007; 370(9581): 59-67. PubMed Abstract | Publisher Full Text | F1000 Recommendation

95. F Acuna SA, Huang JW, Scott AL, et al:: Cancer Screening Recommendations for Solid Organ Transplant Recipients: A Systematic Review of Clinical Practice Guidelines. Am J Transplant. 2017; 17(1): 103-14. PubMed Abstract | Publisher Full Text | F1000 Recommendation

96. Opelz G, Döhler B: Influence of Current and Previous Smoking on Cancer and Mortality After Kidney Transplantation. Transplantation. 2016; 100(1): 227-32. PubMed Abstract | Publisher Full Text

97. Jiyad Z, Olsen CM, Burke MT, et al.: Azathioprine and Risk of Skin Cancer in Organ Transplant Recipients: Systematic Review and Meta-Analysis. Am J Transplant. 2016; 16(12): 3490-503. PubMed Abstract | Publisher Full Tex

98. Coghill AE, Johnson LG, Berg D, et al.: Immunosuppressive Medications and Squamous Cell Skin Carcinoma: Nested Case-Control Study Within the Skin Cancer after Organ Transplant (SCOT) Cohort. Am J Transplant. 2016; 16(2): $565-73$.

PubMed Abstract | Publisher Full Text | Free Full Text

99. Hall EC, Engels EA, Pfeiffer RM, et al:: Association of antibody induction immunosuppression with cancer after kidney transplantation. Transplantation 2015; 99(5): 1051-7.

PubMed Abstract | Publisher Full Text | Free Full Text

100. Jensik SC: Tacrolimus (FK 506) in kidney transplantation: three-year survival results of the US multicenter, randomized, comparative trial. FK 506 Kidney Transplant Study Group. Transplant Proc. 1998; 30(4): 1216-8. PubMed Abstract | Publisher Full Text

101. Webster A, Woodroffe RC, Taylor RS, et al:: Tacrolimus versus cyclosporin as primary immunosuppression for kidney transplant recipients. Cochrane Database Syst Rev. 2005; (4): CD003961. PubMed Abstract | Publisher Full Text

102. Caillard S, Dharnidharka V, Agodoa L, et al.: Posttransplant lymphoproliferative disorders after renal transplantation in the United States in era of modern immunosuppression. Transplantation. 2005; 80(9): 1233-43. PubMed Abstract | Publisher Full Text

103. Opelz G, Döhler B: Lymphomas after solid organ transplantation: a collaborative transplant study report. Am J Transplant. 2004; 4(2): 222-30. PubMed Abstract | Publisher Full Text

104. Kasiske BL, Snyder JJ, Gilbertson DT, et al.: Cancer after kidney transplantation in the United States. Am J Transplant. 2004; 4(6): 905-13. PubMed Abstract | Publisher Full Text

105. Martin ST, Powell JT, Patel M, et al.: Risk of posttransplant lymphoproliferative disorder associated with use of belatacept. Am J Health Syst Pharm. 2013; 70(22): 1977-83.

PubMed Abstract | Publisher Full Text

106. F Pestana JO, Grinyo JM, Vanrenterghem $\mathrm{Y}$, et al:: Three-year outcomes from BENEFIT-EXT: a phase III study of belatacept versus cyclosporine in recipients of extended criteria donor kidneys. Am J Transplant. 2012; 12(3): 630-9. PubMed Abstract | Publisher Full Text | F1000 Recommendation

107. F Vincenti F, Blancho G, Durrbach A, et al.: Five-year safety and efficacy of belatacept in renal transplantation. J Am Soc Nephrol. 2010; 21(9): 1587-96. PubMed Abstract | Publisher Full Text | Free Full Text | F1000 Recommendation

108. Opelz G, Unterrainer C, Süsal C, et al.: Efficacy and safety of antibody induction therapy in the current era of kidney transplantation. Nephrol Dial Transplant. 2016; 31(10): 1730-8. PubMed Abstract | Publisher Full Tex

109. F Guba M, von Breitenbuch $P$, Steinbauer M, et al.: Rapamycin inhibits primary and metastatic tumor growth by antiangiogenesis: involvement of vascular endothelial growth factor. Nat Med. 2002; 8(2): 128-35. PubMed Abstract | Publisher Full Text | F1000 Recommendation

110. Guba M, Graeb C, Jauch KW, et al.: Pro- and anti-cancer effects of immunosuppressive agents used in organ transplantation. Transplantation. 2004; 77(12): 1777-82.

PubMed Abstract | Publisher Full Text

111. Luan FL, Ding R, Sharma VK, et al:: Rapamycin is an effective inhibitor of human renal cancer metastasis. Kidney Int. 2003; 63(3): 917-26. PubMed Abstract | Publisher Full Text

112. Knoll GA, Kokolo MB, Mallick R, et al:: Effect of sirolimus on malignancy and survival after kidney transplantation: systematic review and meta-analysis of individual patient data. BMJ. 2014; 349: g6679 PubMed Abstract | Publisher Full Text | Free Full Text

113. Yanik EL, Gustafson SK, Kasiske BL, et al.: Sirolimus use and cancer incidence among US kidney transplant recipients. Am J Transplant. 2015; 15(1): 129-36. PubMed Abstract | Publisher Full Text

114. Opelz G, Unterrainer C, Süsal C, et al.: Immunosuppression with mammalian target of rapamycin inhibitor and incidence of post-transplant cancer in kidney transplant recipients. Nephrol Dial Transplant. 2016; 31(8): 1360-7. PubMed Abstract | Publisher Full Text

115. Badve SV, Pascoe EM, Burke M, et al.: Mammalian Target of Rapamycin Inhibitors and Clinical Outcomes in Adult Kidney Transplant Recipients. Clin J Am Soc Nephrol. 2016; 11(10): 1845-55. PubMed Abstract | Publisher Full Text | Free Full Text

116. F Ying $\mathrm{T}$, Wong G, Lim W, et al:: De novo or early conversion to everolimus and long-term cancer outcomes in kidney transplant recipients: A trial-based linkage study. Am J Transplant. 2018; 18(12): 2977-86. PubMed Abstract | Publisher Full Text | F1000 Recommendation

117. Karia PS, Azzi JR, Heher EC, et al: Association of Sirolimus Use With Risk for Skin Cancer in a Mixed-Organ Cohort of Solid-Organ Transplant Recipients With a History of Cancer. JAMA Dermatol. 2016; 152(5): 533-40. PubMed Abstract | Publisher Full Text

118. Dharnidharka VR, Schnitzler MA, Chen J, et al: Differential risks for adverse outcomes 3 years after kidney transplantation based on initial immunosuppression regimen: a national study. Transpl Int. 2016; 29(11): 1226-36. PubMed Abstract | Publisher Full Text | Free Full Text

119. F Lim WH, Russ GR, Wong G, et al:: The risk of cancer in kidney transplant recipients may be reduced in those maintained on everolimus and reduced cyclosporine. Kidney Int. 2017; 91(4): 954-63. PubMed Abstract | Publisher Full Text | F1000 Recommendation

120. Nee R, Hurst FP, Dharnidharka VR, et al.: Racial variation in the development of posttransplant lymphoproliferative disorders after renal transplantation. Transplantation. 2011; 92(2): 190-5. PubMed Abstract | Publisher Full Text 
121. Kirk AD, Cherikh WS, Ring M, et al.: Dissociation of depletional induction and posttransplant lymphoproliferative disease in kidney recipients treated with alemtuzumab. Am J Transplant. 2007; 7(11): 2619-25. PubMed Abstract | Publisher Full Text | Free Full Text

122. Kidney Disease: Improving Global Outcomes (KDIGO) Transplant Work Group: KDIGO clinical practice guideline for the care of kidney transplant recipients. Am J Transplant. 2009; 9 Suppl 3: S1-155. PubMed Abstract | Publisher Full Text

123. Campistol JM, Gutierrez-Dalmau A, Torregrosa JV: Conversion to sirolimus: a successful treatment for posttransplantation Kaposi's sarcoma. Transplantation. 2004; 77(5): 760-2. PubMed Abstract | Publisher Full Text

124. Stallone G, Schena A, Infante B, et al.: Sirolimus for Kaposi's sarcoma in renaltransplant recipients. N Engl J Med. 2005; 352(13): 1317-23. PubMed Abstract | Publisher Full Text

125. Lebbé C, Euvrard S, Barrou B, et al.: Sirolimus conversion for patients with posttransplant Kaposi's sarcoma. Am J Transplant. 2006; 6(9): 2164-8. PubMed Abstract | Publisher Full Text

126. Lipson EJ, Forde PM, Hammers HJ, et al.: Antagonists of PD-1 and PD-L1 in Cancer Treatment. Semin Oncol. 2015; 42(4): 587-600. PubMed Abstract | Publisher Full Text | Free Full Text

127. Maggiore U, Pascual J: The Bad and the Good News on Cancer Immunotherapy: Implications for Organ Transplant Recipients. Adv Chronic Kidney Dis. 2016; 23(5): 312-6.

PubMed Abstract | Publisher Full Text

128. Lipson EJ, Bagnasco SM, Moore J Jr, et al:: Tumor Regression and Allograft Rejection after Administration of Anti-PD-1. N Engl J Med. 2016; 374(9): 896-8. PubMed Abstract | Publisher Full Text | Free Full Text

129. Boils CL, Aljadir DN, Cantafio AW: Use of the PD-1 Pathway Inhibitor Nivolumab in a Renal Transplant Patient With Malignancy. Am J Transplant. 2016; 16(8): 2496-7.

PubMed Abstract | Publisher Full Text

130. F Chae YK, Galvez C, Anker JF, et al:: Cancer immunotherapy in a neglected population: The current use and future of T-cell-mediated checkpoint inhibitors in organ transplant patients. Cancer Treat Rev. 2018; 63: 116-21. PubMed Abstract | Publisher Full Text | F1000 Recommendation

131. Fishman JA: Infection in Organ Transplantation. Am J Transplant. 2017; 17(4): 856-79.

PubMed Abstract | Publisher Full Text

132. F Molnar MZ, Alhourani HM, Wall BM, et al:: Association of hepatitis C viral infection with incidence and progression of chronic kidney disease in a large cohort of US veterans. Hepatology. 2015; 61(5): 1495-502. PubMed Abstract | Publisher Full Text | Free Full Text | F1000 Recommendation

133. Fabrizi F, Verdesca S, Messa $P$, et al.: Hepatitis $C$ Virus Infection Increases the Risk of Developing Chronic Kidney Disease: A Systematic Review and MetaAnalysis. Dig Dis Sci. 2015; 22 Suppl 1: 3801-13. PubMed Abstract | Publisher Full Text

134. Fabrizi F, Poordad FF, Martin P: Hepatitis $C$ infection and the patient with endstage renal disease. Hepatology. 2002; 36(1): 3-10. PubMed Abstract | Publisher Full Text

135. Cohen-Bucay A, Francis JM, Gordon CE: Timing of hepatitis $\mathbf{C}$ virus infection treatment in kidney transplant candidates. Hemodial Int. 2018; 22(Suppl 1): S61-S70.

PubMed Abstract | Publisher Full Text

136. Baid-Agrawal S, Pascual M, Moradpour D, et al:: Hepatitis $C$ virus infection and kidney transplantation in 2014: what's new? Am J Transplant. 2014; 14(10): 2206-20.

PubMed Abstract | Publisher Full Text

137. Scott DR, Wong JK, Spicer TS, et al:: Adverse impact of hepatitis $\mathbf{C}$ virus infection on renal replacement therapy and renal transplant patients in Australia and New Zealand. Transplantation. 2010; 90(11): 1165-71. PubMed Abstract | Publisher Full Text

138. Cruzado JM, Carrera $\mathrm{M}$, Torras $\mathrm{J}$, et al.: Hepatitis $\mathrm{C}$ virus infection and de novo glomerular lesions in renal allografts. Am J Transplant. 2001; 1(2): 171-8. PubMed Abstract | Publisher Full Text

139. Díaz JM, Sainz Z, Guirado LL, et al.: Risk factors for cardiovascular disease after renal transplantation. Transplant Proc. 2003; 35(5): 1722-4. PubMed Abstract | Publisher Full Text

140. Fabrizi F, Martin P, Dixit V, et al.: Post-transplant diabetes mellitus and HCV seropositive status after renal transplantation: meta-analysis of clinical studies. Am J Transplant. 2005; 5(10): 2433-40. PubMed Abstract | Publisher Full Text

141. Fabrizi $F$, Messa $P$, Martin $P$, et al.: Hepatitis $C$ virus infection and posttransplant diabetes mellitus among renal transplant patients: a meta-analysis. Int J Artif Organs. 2008; 31(8): 675-82. PubMed Abstract | Publisher Full Tex

142. Bloom RD, Sayer G, Fa K, et al:: Outcome of hepatitis C virus-infected kidney transplant candidates who remain on the waiting list. Am J Transplant. 2005 5(1): 139-44.

PubMed Abstract | Publisher Full Text

143. Roth D, Gaynor JJ, Reddy KR, et al:: Effect of kidney transplantation on outcomes among patients with hepatitis C. J Am Soc Nephrol. 2011; 22(6):
$1152-60$

PubMed Abstract | Publisher Full Text | Free Full Text

144. Sezer S, Ozdemir FN, Akcay A, et al.: Renal transplantation offers a better survival in HCV-infected ESRD patients. Clin Transplant. 2004; 18(5): 619-23. PubMed Abstract | Publisher Full Text

145. Wei F, Liu J, Liu F, et al.: Interferon-based anti-viral therapy for hepatitis C virus infection after renal transplantation: an updated meta-analysis. PLOS One. 2014: 9(4): e90611.

PubMed Abstract | Publisher Full Text | Free Full Text

146. Feld JJ, Jacobson IM, Sulkowski MS, et al:: Ribavirin revisited in the era of direct-acting antiviral therapy for hepatitis C virus infection. Liver Int. 2017; 37(1): 5-18.

PubMed Abstract | Publisher Full Text | Free Full Text

147. Vierling JM, Lawitz E, Reddy KR, et al:: RUBY-I: Safety and Efficacy of Ombitasvir/Paritaprevir/ Ritonavir ana Dasabuvir with or without Ribavirin in Adults with Genotype 1 Chronic Hepatitis C Virus (HCV) Infection with Severe Renal Impairment or End-Stage Renal Disease (Abstract). Hepatology. 2016; 64 $441 \mathrm{~A}$.

Reference Source

148. Pockros PJ, Reddy KR, Mantry PS, et al.: Efficacy of Direct-Acting Antiviral Combination for Patients With Hepatitis C Virus Genotype 1 Infection and Severe Renal Impairment or End-Stage Renal Disease. Gastroenterology. 2016; 150(7): 1590-8 PubMed Abstract | Publisher Full Text

149. Roth D, Nelson DR, Bruchfeld A, et al:: Grazoprevir plus elbasvir in treatmentnaive and treatment-experienced patients with hepatitis $C$ virus genotype 1 infection and stage 4-5 chronic kidney disease (the C-SURFER study): a combination phase 3 study. Lancet. 2015; 386(10003): 1537-45 PubMed Abstract | Publisher Full Text

150. Gane EJ, Solà R, Cohen E, et al: RUBY-II: Efficacy and Safety of a Ribavirinfree Ombitasvir/Paritaprevir/Ritonavir \pm Dasabuvir Regimen in Patients with Severe Renal Impairment or End-Stage Renal Disease and HCV Genotypes 1a or 4 Infection (Abstract). Hepatology. 2016; 64: 470-1A. Reference Source

151. Gane EJ, Lawitz E, Pugatch D, et al.: EXPEDITION-IV: Safety and Efficacy of GLE/PIB in Adults with renal impairment and Chronic Hepatitis C Virus Genotype 1 - 6 Infection. (Abstract). Hepatology. 2016; 64: 1125A. Reference Source

152. F Gane E, Lawitz E, Pugatch D, et al.: Glecaprevir and Pibrentasvir in Patients with HCV and Severe Renal Impairment. N Engl J Med. 2017; 377(15): 1448-55. PubMed Abstract | Publisher Full Text | F1000 Recommendation

153. F Colombo M, Aghemo A, Liu H, et al.: Treatment With Ledipasvir-Sofosbuvir or 12 or 24 Weeks in Kidney Transplant Recipients With Chronic Hepatitis C Virus Genotype 1 or 4 Infection: A Randomized Trial. Ann Intern Med. 2017; 166(2): 109-117.

PubMed Abstract | Publisher Full Text | F1000 Recommendation

154. Reau N, Kwo PY, Rhee S, et al:: MAGELLAN-2: Safety and efficacy of glecaprevir/pibrentasvir in liver or renal transplant adults with chronic hepatitis C genotype 1-6 infection. $J$ Hepatol. 2017; 66(1): S90-S91. Publisher Full Text

155. Fernández I, Muñoz-Gómez R, Pascasio JM, et al:: Efficacy and tolerability of interferon-free antiviral therapy in kidney transplant recipients with chronic hepatitis C. J Hepatol. 2017; 66(4): 718-23. PubMed Abstract | Publisher Full Text

156. Sawinski D, Kaur N, Ajeti A, et al.: Successful Treatment of Hepatitis C in Rena Transplant Recipients With Direct-Acting Antiviral Agents. Am J Transplant. 2016; 16(5): 1588-95. PubMed Abstract | Publisher Full Text

157. Gallegos-Orozco JF, Kim R, Thiesset HF, et al:: Early Results of Pilot Study Using Hepatitis C Virus (HCV) Positive Kidneys to Transplant HCV Infected Patients with End-Stage Renal Disease Allowing for Successful InterferonFree Direct Acting Antiviral Therapy after Transplantation. Cureus. 2016; 8(11) e890. PubMed Abstract | Publisher Full Text | Free Full Text

158. $\mathrm{F}$ Bhamidimarri KR, Ladino $M$, Pedraza $F$, et al.: Transplantation of kidneys from hepatitis $C$-positive donors into hepatitis $C$ virus-infected recipients followed by early initiation of direct acting antiviral therapy: a single-cente retrospective study. Transpl Int. 2017; 30(9): 865-73. PublMed Abstract | Publisher Full Text | F1000 Recommendation

159. Kamar N, Marion O, Rostaing L, et al:: Efficacy and Safety of SofosbuvirBased Antiviral Therapy to Treat Hepatitis C Virus Infection After Kidney Transplantation. Am J Transplant. 2016; 16(5): 1474-9. PubMed Abstract | Publisher Full Text

160. F Lubetzky M, Chun S, Joelson A, et al.: Safety and Efficacy of Treatment of Hepatitis C in Kidney Transplant Recipients With Directly Acting Antivira Agents. Transplantation. 2017; 101(7): 1704-10. PubMed Abstract | Publisher Full Text | F1000 Recommendation

161. Lin MV, Sise ME, Pavlakis M, et al.: Efficacy and Safety of Direct Acting Antivirals in Kidney Transplant Recipients with Chronic Hepatitis C Virus Infection. PLoS One. 2016; 11(7): e0158431. PubMed Abstract | Publisher Full Text | Free Full Text

162. Goel A, Bhadauria DS, Kaul A, et al.: Experience with direct acting anti-viral 
agents for treating hepatitis $\mathbf{C}$ virus infection in renal transplant recipients. Indian J Gastroenterol. 2017; 36(2): 137-40.

PubMed Abstract | Publisher Full Text

163. F Eisenberger $\mathrm{U}$, Guberina $\mathrm{H}$, Willuweit $\mathrm{K}$, et al:: Successful Treatment of Chronic Hepatitis C Virus Infection With Sofosbuvir and Ledipasvir in Rena Transplant Recipients. Transplantation. 2017; 101(5): 980-6. PubMed Abstract | Publisher Full Text | F1000 Recommendation

164. F Mavilia MG, Wu GY: HBV-HCV Coinfection: Viral Interactions, Management and Viral Reactivation. J Clin Transl Hepatol. 2018; 6(3): 296-305. PubMed Abstract | Publisher Full Text | Free Full Text | F1000 Recommendation

165. Kucirka LM, Singer AL, Ros RL, et al:: Underutilization of hepatitis C-positive kidneys for hepatitis C-positive recipients. Am J Transplant. 2010; 10(5): 1238-46. PubMed Abstract | Publisher Full Text

166. Goldberg DS, Abt PL, Blumberg EA, et al.: Trial of Transplantation of HCVInfected Kidneys into Uninfected Recipients. N Engl J Med. 2017; 376(24): $2394-5$.

PubMed Abstract | Publisher Full Tex

167. Reese PP, Abt PL, Blumberg EA, et al.: Transplanting Hepatitis C-Positive Kidneys. N Engl J Med. 2015; 373(4): 303-5.

PubMed Abstract | Publisher Full Text

168. F Reese PP, Abt PL, Blumberg EA, et al:: Twelve-Month Outcomes After Transplant of Hepatitis C-Infected Kidneys Into Uninfected Recipients: A Single-Group Trial. Ann Intern Med. 2018; 169(5): 273-81.

PubMed Abstract | Publisher Full Text | F1000 Recommendation

169. F Durand CM, Bowring MG, Brown DM, et al.: Direct-Acting Antiviral Prophylaxis in Kidney Transplantation From Hepatitis C Virus-Infected Donors to Noninfected Recipients: An Open-Label Nonrandomized Trial. Ann Intern Med. 2018; 168(8): 533-540.

PubMed Abstract | Publisher Full Text | Free Full Text | F1000 Recommendation

170. Durand C, Brown D, Wesson R, et al: EXPANDER-1: Exploring Rena Transplants Using Hepatitis-C Infected Donors for HCV-Negative Recipients. (abstract). Am J Transplant. 2017; 17(suppl 3): 207. Reference Source

171. Kotton CN, Kumar D, Caliendo AM, et al: Updated international consensus guidelines on the management of cytomegalovirus in solid-organ transplantation. Transplantation. 2013; 96(4): 333-60. PubMed Abstract | Publisher Full Text

172. Kotton CN, Kumar D, Caliendo AM, et al:: The Third International Consensus Guidelines on the Management of Cytomegalovirus in Solid-organ Transplantation. Transplantation. 2018; 102(6): 900-31. PubMed Abstract | Publisher Full Tex

173. Tedesco-Silva H, Felipe C, Ferreira A, et al:: Reduced Incidence of Cytomegalovirus Infection in Kidney Transplant Recipients Receiving Everolimus and Reduced Tacrolimus Doses. Am J Transplant. 2015; 15(10): 2655-64.

PubMed Abstract | Publisher Full Text

174. Webster AC, Lee VW, Chapman JR, et al: Target of rapamycin inhibitors (sirolimus and everolimus) for primary immunosuppression of kidney transplant recipients: a systematic review and meta-analysis of randomized trials. Transplantation. 2006; 81(9): 1234-48. PubMed Abstract | Publisher Full Tex

175. Lim WH, Eris J, Kanellis J, et al:: A systematic review of conversion from calcineurin inhibitor to mammalian target of rapamycin inhibitors for maintenance immunosuppression in kidney transplant recipients. $A m$ Transplant. 2014; 14(9): 2106-19. PubMed Abstract | Publisher Full Text

176. F Mallat SG, Tanios BY, Itani HS, et al:: CMV and BKPyV Infections in Renal Transplant Recipients Receiving an mTOR Inhibitor-Based Regimen Versus a CNI-Based Regimen: A Systematic Review and Meta-Analysis of Randomized, Controlled Trials. Clin J Am Soc Nephrol. 2017; 12(8): 1321-36. PubMed Abstract | Publisher Full Text | Free Full Text | F1000 Recommendation

177. Mourad G, Garrigue V, Squifflet JP, et al.: Induction versus noninduction in renal transplant recipients with tacrolimus-based immunosuppression. Transplantation. 2001; 72(6): 1050-5. PubMed Abstract | Publisher Full Text

178. Charpentier B, Rostaing L, Berthoux F, et al.: A three-arm study comparing immediate tacrolimus therapy with antithymocyte globulin induction therapy followed by tacrolimus or cyclosporine $\mathrm{A}$ in adult renal transplant recipients. Transplantation. 2003; 75(6): 844-51. PubMed Abstract | Publisher Full Tex

179. Luan FL, Samaniego M, Kommareddi M, et al:: Choice of induction regimens on the risk of cytomegalovirus infection in donor-positive and recipient-negative kidney transplant recipients. Transpl Infect Dis. 2010; 12(6): 473-9. PubMed Abstract | Publisher Full Text | Free Full Text

180. Preiksaitis JK, Hayden RT, Tong Y, et al.: Are We There Yet? Impact of the First International Standard for Cytomegalovirus DNA on the Harmonization of Results Reported on Plasma Samples. Clin Infect Dis. 2016; 63(5): 583-9. PubMed Abstract | Publisher Full Text

181. Pang XL, Fox JD, Fenton JM, et al:: Interlaboratory comparison of cytomegalovirus viral load assays. Am J Transplant. 2009; 9(2): 258-68. PubMed Abstract | Publisher Full Text

182. Khoury JA, Storch GA, Bohl DL, et al.: Prophylactic versus preemptive oral valganciclovir for the management of cytomegalovirus infection in adult renal transplant recipients. Am J Transplant. 2006; 6(9): 2134-43.

PubMed Abstract | Publisher Full Text

183. Asberg A, Humar A, Rollag H, et al:: Oral valganciclovir is noninferior to intravenous ganciclovir for the treatment of cytomegalovirus disease in solid organ transplant recipients. Am J Transplant. 2007; 7(9): 2106-13. PubMed Abstract | Publisher Full Text

184. Asberg A, Jardine AG, Bignamini AA, et al.: Effects of the intensity of immunosuppressive therapy on outcome of treatment for CMV disease in organ transplant recipients. Am J Transplant. 2010; 10(8): 1881-8. PubMed Abstract | Publisher Full Text

185. Hirsch $\mathrm{HH}$, Knowles W, Dickenmann M, et al:: Prospective study of polyomavirus type BK replication and nephropathy in renal-transplant recipients. $N$ Engl $J$ Med. 2002; 347(7): 488-96. PubMed Abstract | Publisher Full Tex

186. Hirsch HH, Brennan DC, Drachenberg CB, et al:: Polyomavirus-associated nephropathy in renal transplantation: interdisciplinary analyses and recommendations. Transplantation. 2005; 79(10): 1277-86. PubMed Abstract | Publisher Full Text

187. Dharnidharka VR, Cherikh WS, Abbott KC: An OPTN analysis of national registry data on treatment of BK virus allograft nephropathy in the United States. Transplantation. 2009; 87(7): 1019-26. PubMed Abstract | Publisher Full Text

188. Schold JD, Rehman S, Kayle LK, et al:: Treatment for BK virus: incidence, risk factors and outcomes for kidney transplant recipients in the United States. Transpl Int. 2009; 22(6): 626-34. PubMed Abstract | Publisher Full Text

189. Schachtner T, Stein M, Babel N, et al:: The Loss of BKV-specific Immunity From Pretransplantation to Posttransplantation Identifies Kidney Transplant Recipients at Increased Risk of BKV Replication. Am J Transplant. 2015; 15(8): 2159-69. PubMed Abstract | Publisher Full Tex

190. F Schaenman JM, Korin Y, Sidwell T, et al.: Increased Frequency of BK VirusSpecific Polyfunctional CD8+ T Cells Predict Successful Control of BK Viremia After Kidney Transplantation. Transplantation. 2017; 101(6): 1479-87. PubMed Abstract | Publisher Full Text | Free Full Text | F1000 Recommendation

191. F Wunderink HF, van der Meijden E, van der Blij-de Brouwer CS, et al.: Pretransplantation Donor-Recipient Pair Seroreactivity Against BK Polyomavirus Predicts Viremia and Nephropathy After Kidney Transplantation. Am J Transplant. 2017; 17(1): 161-72. PubMed Abstract | Publisher Full Text | F1000 Recommendation

192. F Abend JR, Changala M, Sathe A, et al.: Correlation of BK Virus Neutralizing Serostatus With the Incidence of BK Viremia in Kidney Transplant Recipients. Transplantation. 2017; 101(6): 1495-505. PubMed Abstract | Publisher Full Text | F1000 Recommendation

193. Thangaraju S, Gill J, Wright A, et al.: Risk Factors for BK Polyoma Virus Treatment and Association of Treatment With Kidney Transplant Failure: Insights From a Paired Kidney Analysis. Transplantation. 2016; 100(4): 854-61. PubMed Abstract | Publisher Full Text

194. Huang G, Chen LZ, Qiu J, et al:: Prospective study of polyomavirus BK replication and nephropathy in renal transplant recipients in China: a singlecenter analysis of incidence, reduction in immunosuppression and clinical course. Clin Transplant. 2010; 24(5): 599-609. PubMed Abstract | Publisher Full Text

195. Nickeleit V, Klimkait T, Binet IF, et al: Testing for polyomavirus type BK DNA in plasma to identify renal-allograft recipients with viral nephropathy. $N$ Engl J Med. 2000; 342(18): 1309-15. PubMed Abstract | Publisher Full Text

196. Hirsch HH: Polyomavirus BK nephropathy: a (re-)emerging complication in renal transplantation. Am J Transplant. 2002; 2(1): 25-30. PubMed Abstract | Publisher Full Text

197. Viscount HB, Eid AJ, Espy MJ, et al.: Polyomavirus polymerase chain reaction as a surrogate marker of polyomavirus-associated nephropathy. Transplantation. 2007; 84(3): 340-5. PubMed Abstract | Publisher Full Text

198. Randhawa $\mathrm{P}$, Ho A, Shapiro R, et al.: Correlates of quantitative measurement of BK polyomavirus (BKV) DNA with clinical course of BKV infection in renal transplant patients. J Clin Microbiol. 2004; 42(3): 1176-80. PubMed Abstract | Publisher Full Text | Free Full Text

199. Humar A, Michaels M, AST ID Working Group on Infectious Disease Monitoring American Society of Transplantation recommendations for screening, monitoring and reporting of infectious complications in immunosuppression trials in recipients of organ transplantation. Am J Transplant. 2006; 6(2): 262-74. PubMed Abstract | Publisher Full Text

200. Randhawa PS, Finkelstein S, Scantlebury V, et al:: Human polyoma virusassociated interstitial nephritis in the allograft kidney. Transplantation. 1999; 67(1): 103-9. PubMed Abstract | Publisher Full Text

201. Saad ER, Bresnahan BA, Cohen EP, et al.: Successful treatment of BK viremia using reduction in immunosuppression without antiviral therapy. Transplantation. 2008; 85(6): 850-4. PubMed Abstract | Publisher Full Text

202. Wadei HM, Rule AD, Lewin M, et al.: Kidney transplant function and histological 
clearance of virus following diagnosis of polyomavirus-associated nephropathy (PVAN). Am J Transplant. 2006; 6(5 Pt 1): 1025-32. PubMed Abstract | Publisher Full Text

203. Weiss AS, Gralla J, Chan L, et al:: Aggressive immunosuppression minimization reduces graft loss following diagnosis of $\mathrm{BK}$ virus-associated nephropathy: a comparison of two reduction strategies. Clin J Am Soc Nephrol. 2008; 3(6):

$1812-9$.

PubMed Abstract | Publisher Full Text | Free Full Text

204. Brennan DC, Agha I, Bohl DL, et al.: Incidence of BK with tacrolimus versus cyclosporine and impact of preemptive immunosuppression reduction. $A m \mathrm{~J}$ Transplant. 2005; 5(3): 582-94. PubMed Abstract | Publisher Full Text

205. Johnston O, Jaswal D, Gill JS, et al.: Treatment of polyomavirus infection in kidney transplant recipients: a systematic review. Transplantation. 2010; 89(9): 1057-70.

PubMed Abstract | Publisher Full Text

206. Randhawa P, Pastrana DV, Zeng G, et al:: Commercially available immunoglobulins contain virus neutralizing antibodies against all major genotypes of polyomavirus BK. Am J Transplant. 2015; 15(4): 1014-20. PubMed Abstract | Publisher Full Text

207. Sener A, House AA, Jevnikar AM, et al:: Intravenous immunoglobulin as a treatment for BK virus associated nephropathy: one-year follow-up of renal allograft recipients. Transplantation. 2006; 81(1): 117-20. PubMed Abstract | Publisher Full Text

208. Vu D, Shah T, Ansari J, et al:: Efficacy of intravenous immunoglobulin in the treatment of persistent BK viremia and BK virus nephropathy in renal transplant recipients. Transplant Proc. 2015; 47(2): 394-8. PubMed Abstract | Publisher Full Text

209. Lee BT, Gabardi S, Grafals M, et al:: Efficacy of levofloxacin in the treatment of BK viremia: a multicenter, double-blinded, randomized, placebo-controlled trial. Clin J Am Soc Nephrol. 2014; 9(3): 583-9. PubMed Abstract | Publisher Full Text | Free Full Text

210. F Knoll GA, Humar A, Fergusson D, et al.: Levofloxacin for BK virus prophylaxis following kidney transplantation: a randomized clinical trial. JAMA. 2014; 312(20): 2106-14.

PubMed Abstract | Publisher Full Text | F1000 Recommendation 


\section{Open Peer Review}

\section{Current Peer Review Status:}

\section{Editorial Note on the Review Process}

Faculty Reviews are review articles written by the prestigious Members of Faculty Opinions. The articles are commissioned and peer reviewed before publication to ensure that the final, published version is comprehensive and accessible. The reviewers who approved the final version are listed with their names and affiliations.

\section{The reviewers who approved this article are:}

\section{Version 1}

\section{Arnaldo Figueiredo}

Department of Urology and Renal Transplantation, Coimbra University Hospital, Coimbra, Portugal Competing Interests: No competing interests were disclosed.

\section{Magdalena Durlik}

Department of Transplantation Medicine, Nephrology and Internal Diseases, Medical University of Warsaw, Warsaw, Poland

Competing Interests: No competing interests were disclosed.

\section{Jeremy $\mathbf{R}$ Chapman}

Centre for Transplant and Renal Research, Westmead Hospital, Westmead, NSW, Australia

Competing Interests: No competing interests were disclosed.

The benefits of publishing with F1000Research:

- Your article is published within days, with no editorial bias

- You can publish traditional articles, null/negative results, case reports, data notes and more

- The peer review process is transparent and collaborative

- Your article is indexed in PubMed after passing peer review

- Dedicated customer support at every stage

For pre-submission enquiries, contact research@f1000.com 